\title{
Unraveling biogeochemical phosphorus dynamics in hyperarid Mars-analogue soils using stable oxygen isotopes in phosphate
}

\author{
Jianxun Shen ${ }^{1}$ (D) | Andrew C. Smith ${ }^{2}$ | Mark W. Claire ${ }^{1}$ | Aubrey L. Zerkle ${ }^{1}$ (D)
}

${ }^{1}$ School of Earth and Environmental Sciences and Centre for Exoplanet Science, University of St Andrews, St Andrews, UK

${ }^{2}$ NERC Isotope Geosciences Facilities, British Geological Survey, Nottingham, UK

\section{Correspondence}

Jianxun Shen, School of Earth and Environmental Sciences and Centre for Exoplanet Science, University of St Andrews, St Andrews KY16 9AL, UK.

Email: js365@st-andrews.ac.uk

\section{Funding Information}

This project has received funding from the European Research Council under the European Union's Horizon 2020 Research and Innovation Programme (Grant 678812 to M.W.C.). J.S. also acknowledges support from the China Scholarship Council (CSC).

\begin{abstract}
With annual precipitation less than $20 \mathrm{~mm}$ and extreme UV intensity, the Atacama Desert in northern Chile has long been utilized as an analogue for recent Mars. In these hyperarid environments, water and biomass are extremely limited, and thus, it becomes difficult to generate a full picture of biogeochemical phosphate-water dynamics. To address this problem, we sampled soils from five Atacama study sites and conducted three main analyses-stable oxygen isotopes in phosphate, enzyme pathway predictions, and cell culture experiments. We found that high sedimentation rates decrease the relative size of the organic phosphorus pool, which appears to hinder extremophiles. Phosphoenzyme and pathway prediction analyses imply that inorganic pyrophosphatase is the most likely catalytic agent to cycle $\mathrm{P}$ in these environments, and this process will rapidly overtake other $\mathrm{P}$ utilization strategies. In these soils, the biogenic $\delta^{18} \mathrm{O}$ signatures of the soil phosphate $\left(\delta^{18} \mathrm{O}_{\mathrm{PO} 4}\right)$ can slowly overprint lithogenic $\delta^{18} \mathrm{O}_{\mathrm{PO} 4}$ values over a timescale of tens to hundreds of millions of years when annual precipitation is more than $10 \mathrm{~mm}$. The $\delta^{18} \mathrm{O}_{\mathrm{PO} 4}$ of calcium-bound phosphate minerals seems to preserve the $\delta^{18} \mathrm{O}$ signature of the water used for biogeochemical P cycling, pointing toward sporadic rainfall and gypsum hydration water as key moisture sources. Where precipitation is less than $2 \mathrm{~mm}$, biological cycling is restricted and bedrock $\delta^{18} \mathrm{O}_{\mathrm{PO} 4}$ values are preserved. This study demonstrates the utility of $\delta^{18} \mathrm{O}_{\mathrm{PO} 4}$ values as indicative of biogeochemical cycling and hydrodynamics in an extremely dry Mars-analogue environment.
\end{abstract}

\section{KEYWORDS}

biosignature, hyperarid, Mars, metabolic pathway, phosphate, stable oxygen isotope

\section{1 | INTRODUCTION}

Phosphorus $(\mathrm{P})$ is a crucial bioelement for life on Earth, as it is utilized in the formation of ATP/GTP, genetic materials (DNA/RNA), cell membrane phospholipids, and sugar phosphates formed as intermediate products during sugar metabolism (George et al., 2018). Due to the role P plays in the cycle of life, it is critical to understand $\mathrm{P}$ uptake and utilization pathways and their interaction with other key nutrients, such as carbon (C) and nitrogen (N). This is especially true in extreme environments, where organisms are often forced to find novel adaptation strategies for survival and C:N:P ratios may be atypical (Huang et al., 2018; Tian, Chen, Zhang, Melillo, \& Hall, 2010). These environments also act as a unique analogue for investigating the potential for life on other planets including Mars, where in the planet's early history active hydrology promoted the release of nutrients making $\mathrm{P}$ bioavailable (Komatsu \& Ori, 2000;

This is an open access article under the terms of the Creative Commons Attribution License, which permits use, distribution and reproduction in any medium, 
Weckwerth \& Schidlowski, 1995). Significantly, Komatsu \& Ori (2000) and Weckwerth \& Schidlowski (1995) have suggested that water-mineral interaction on early wet Mars may have allowed for up to 45 times higher phosphate release rates than on early Earth. As a result, the bioavailable phosphate concentration in Martian sediments is about twice that estimated for prebiotic Earth (Adcock, Hausrath, \& Forster, 2013), with $\mathrm{P}_{2} \mathrm{O}_{5}$ of surface sediments varying between 0.15 and 5.19 wt\% as determined by Mars Exploration Rovers (Yen et al., 2006). Since early Mars has all the makings of a planet which could have supported past life, it is critically important to identify biogeochemical signatures that can persist through many millennia of hyperarid conditions such as those found on Mars today.

The Atacama Desert is one of the driest and oldest temperate deserts (Dunai, Lopez, \& Juez-Larre, 2005; Hartley, Chong, Houston, \& Mather, 2005) that reaches the extreme limit of life (NavarroGonzalez et al., 2003). This desert occupies around $105,000 \mathrm{~km}^{2}$ of northern Chile, and has remained extremely dry for the past $150 \mathrm{Myr}$ (Hartley et al., 2005), with annual precipitation at the hyperarid core less than 2 mm (Houston, 2006) for more than 10 Myr (Sun, Bao, Reich, \& Hemming, 2018). Alongside aridity, extremes in UV irradiation are similar to high levels of UV delivered to exposed Martian surfaces, approximately $150 \mathrm{kWh} / \mathrm{m}^{2} \mathrm{UV}-\mathrm{A}(315-400 \mathrm{~nm})$ and $5 \mathrm{kWh} /$ $\mathrm{m}^{2}$ UV-B (280-315 nm) (Cordero et al., 2018). UV irradiation causes organic degradation, resulting in an oligotrophic terrain, and the lack of precipitation reduces leaching and runoff, meaning phosphate minerals can be preserved. This location is therefore ideal to investigate both the dynamics of $\mathrm{P}$ cycling in relation to other key nutrients $(C, N)$ in hostile environments, and to potentially identify long-lived biomarkers of life in an environment similar to that found on Mars.

The biogeochemical cycling of $\mathrm{P}$ is less well-studied than $\mathrm{C}, \mathrm{N}$, and $\mathrm{S}$ in modern terrestrial soils. This is because $\mathrm{P}$ usually remains in the form of orthophosphate $\left(\mathrm{PO}_{4}{ }^{3-}, \mathrm{HPO}_{4}{ }^{2-}\right.$, or $\left.\mathrm{H}_{2} \mathrm{PO}_{4}{ }^{-}\right)$and only has one stable isotope, ${ }^{31} \mathrm{P}$. These facts render it relatively difficult to track $\mathrm{P}$ in biosystems and understand its reaction processes. Recently, however, methods have used phosphate-bound stable oxygen isotopes (hereafter noted as $\left.\delta^{18} \mathrm{O}_{\mathrm{PO} 4}\right)$ as a tracer for the detection of biological activity (Blake, Chang, \& Lepland, 2010; Blake, O'Neil, \& Surkov, 2005; Jaisi \& Blake, 2014; Stout, Joshi, Kana, \& Jaisi, 2014; Tamburini, Pfahler, von Sperber, Frossard, \& Bernasconi, 2014), since phosphorus is normally associated with oxygen in both abiotic and organic forms.
Stable oxygen isotope values are reported in parts per thousand (\%) using the standard $\delta$ notation:

$$
\delta^{18} \mathrm{O}(\%)=\left(\frac{\mathrm{R}_{\text {sample }}}{\mathrm{R}_{\text {standard }}}-1\right) \times 1000
$$

where $\mathrm{R}_{\text {sample }}$ is the ${ }^{18} \mathrm{O} /{ }^{16} \mathrm{O}$ ratio in a given sample and $\mathrm{R}_{\text {standard }}$ is the ${ }^{18} \mathrm{O} /{ }^{16} \mathrm{O}$ ratio of Vienna Standard Mean Ocean Water (VSMOW). We further define an isotopic fractionation factor, $\alpha$, as follows:

$$
\alpha_{p-r}=\frac{R_{\text {product }}}{R_{\text {reactant }}}
$$

where $\mathrm{R}_{\text {product }}$ and $\mathrm{R}_{\text {reactant }}$ are the ${ }^{18} \mathrm{O} /{ }^{16} \mathrm{O}$ ratios in the product and reactant, respectively. The isotopic enrichment factor, $\varepsilon_{p-r}$ is then defined as follows:

$$
\varepsilon_{\mathrm{p}-\mathrm{r}}(\%)=\left(\alpha_{\mathrm{p}-\mathrm{r}}-1\right) \times 1000
$$

The principle of this method for tracing $\mathrm{P}$ cycling using the $\delta^{18} \mathrm{O}_{\mathrm{PO} 4}$ signature relies on the relative stability of the $\mathrm{P}-\mathrm{O}$ bond under abiotic processing. Abiotic $\mathrm{P}$ transformations (including phosphate precipitation, UV photolysis and decay of organophosphorus, and solubilization) do not introduce significant oxygen isotope fractionations in phosphate (Figure 1), resulting in an isotopic signature which is theoretically extremely long-lived (Dahms \& Boyer, 1973; Jaisi, Blake, \& Kukkadapu, 2010; Kolodny, Luz, \& Navon, 1983; Tudge, 1960). However, where biological uptake and processing of $\mathrm{P}$ occurs the $\mathrm{P}-\mathrm{O}$ bond can be broken, enabling isotopic exchange of phosphate $\mathrm{O}$ with surrounding $\mathrm{O}$ sources (normally soil or cellular water). Hence, deviations in $\delta^{18} \mathrm{O}_{\mathrm{PO} 4}$ from the source mineral signature can potentially be utilized as a biosignature for life (Blake, Alt, \& Martini, 2001).

There are three main biological pathways that can cause isotopic fractionations in $\delta^{18} \mathrm{O}_{\mathrm{PO} 4}$ (Blake et al., 2001). These biological processes include the following: (a) microbial $\mathrm{P}$ uptake, with $\varepsilon$ of about -3\%o (Blake et al., 2005; Gross et al., 2015); (b) phosphoester hydrolysis by various types of phosphoenzymes (e.g., alkaline and acid phosphatase, DNase, RNase, 5'-nucleotidase, and phytases), with $\varepsilon$ varying between -30 and $+20 \%$ (Liang \& Blake, 2006, 2009; von Sperber, Kries, Tamburini, Bernasconi, \& Frossard, 2014); and (c) microbial hydrolysis of diphosphate by inorganic pyrophosphatase,

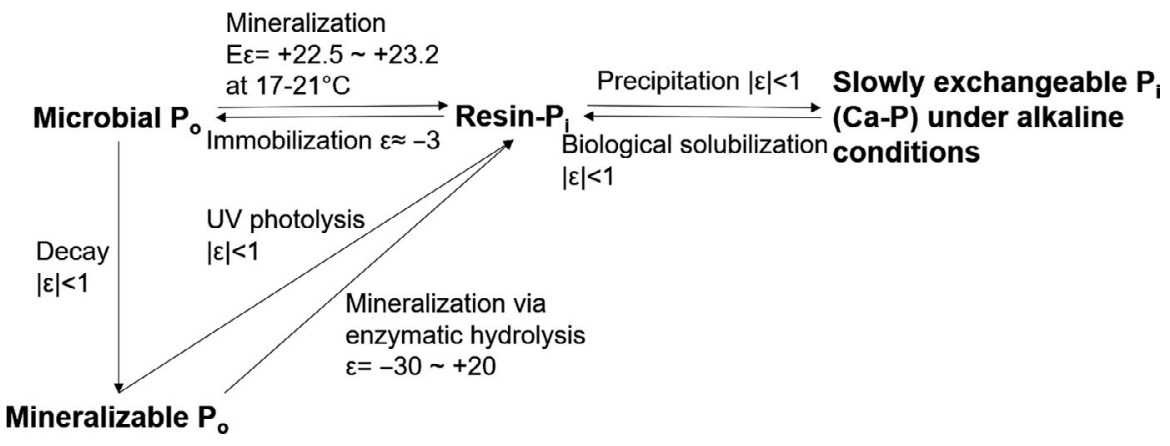

FIGURE 1 Hypothetical phosphorus cycle in a hyperarid environment $\left(\mathrm{P}_{\mathrm{i}}\right.$, inorganic $\mathrm{P} ; \mathrm{P}_{\mathrm{o}}$, organic $\mathrm{P} ; \mathrm{E} \varepsilon$, isotopic enrichment factor at equilibration with water) 
with $\varepsilon$ as defined by Eq. (4) at equilibration with water and soil temperature (Figure 1) (Chang \& Blake, 2015; Granger et al., 2018; Pistocchi et al., 2017).

$$
\mathrm{E} \delta^{18} \mathrm{O}_{\mathrm{PO} 4}=-0.18 \mathrm{~T}+26.3+\delta^{18} \mathrm{O}_{\mathrm{H} 2 \mathrm{O}}
$$

where $\mathrm{E}^{18} \mathrm{O}_{\mathrm{PO} 4}$ is the ${ }^{18} \mathrm{O} /{ }^{16} \mathrm{O}$ ratio of phosphate at equilibration with water catalyzed by inorganic pyrophosphatase, $\mathrm{T}$ is temperature in ${ }^{\circ} \mathrm{C}$, and $\delta^{18} \mathrm{O}_{\mathrm{H} 2 \mathrm{O}}$ is the $\delta^{18} \mathrm{O}$ of ambient water.

We can therefore assess the extent to which abiotic or biotic processes have impacted $\mathrm{P}$ by measuring the $\delta^{18} \mathrm{O}_{\mathrm{PO} 4}$ signature of soils. To investigate deeper into the $\mathrm{P}$ cycle, we extract different forms of $\mathrm{P}$ using well-developed chemical extractions (Olsen, 1954) and analyze $\delta^{18} \mathrm{O}_{\mathrm{PO} 4}$ for individual pools of phosphate. By measuring the $\delta^{18} \mathrm{O}_{\mathrm{PO} 4}$ of each extract, we can identify the extent to which each pool has been subjected to biological utilization. In this study, we focused on four extracted pools of soil phosphate, operationally defined as (a) resin-extractable $\mathrm{P}$, (b) microbial $\mathrm{P}$, (c) $\mathrm{NaOH}$-extractable $\mathrm{Al} / \mathrm{Fe}$ oxide-bound $\mathrm{P}$ and organic $\mathrm{P}$, and (d) $\mathrm{HCl}$-extractable calcium-bound $\mathrm{P}$ (Ca-P).

In normal soil environments, resin-extractable $P$ is turned over on timescales from seconds to minutes, oxide-bound $P$ is recycled on weekly to monthly timescales, and Ca-bound $\mathrm{P}$ over years to millennia (Helfenstein et al., 2020; Helfenstein et al., 2018). The least bioavailable $\mathrm{P}$ pool is therefore normally $\mathrm{Ca}$-bound $\mathrm{P}$. In an alkaline environment like the Atacama Desert (Crits-Christoph et al., 2013; Makhalanyane et al., 2015; Shen, Zerkle, Stueken, \& Claire, 2019) or on Mars (pH 7.2-8.2; (Hecht et al., 2009; Smith et al., 2009)), where resin-extractable $\mathrm{P}$ (bioavailable $\mathrm{P}$ ) is high, it would tend to be sorbed by calcite (Reddy, Wetzel, \& Kadlec, 2005) and incorporated through precipitation into Ca-bound $P$ mineral phases (Kreuzeder, 2011), making it less bioavailable (Oburger, Jones, \& Wenzel, 2011; Urrutia et al., 2014). However, where this $C a-b o u n d ~ P$ is a major source of $P$ within a biological system it can be reversibly solubilized by the excretion of acids by specialized microbial communities, breaking down Ca-P and once again making it bioavailable. Alternatively, Ca-bound $\mathrm{P}$ can dissolve abiotically over an extremely prolonged period under alkaline conditions (Guidry \& Mackenzie, 2003) such as those found in Atacama soils. In non-arid soil samples, the concentration of Ca-P is usually low and hard to detect (Amelung et al., 2018). However, the relative pool size increases significantly in desert environments (Angert, Weiner, Mazeh, \& Sternberg, 2012; Helfenstein et al., 2018).

Where exchange is rapid, or $\mathrm{P}$ cycling long enough, biogenic $\mathrm{P}$ becomes the main component of the Ca-P pool; however, this can take thousands of years (Tamburini et al., 2012). Previous studies have shown that in low precipitation environments, the exchange rate between resin-extractable $\mathrm{P}$ and $\mathrm{Ca}-\mathrm{P}$ is slowed and pedogenic $\mathrm{P}$ may persist in the $\mathrm{Ca}-\mathrm{P}$ pool for hundreds of thousands of years (Helfenstein et al., 2018). In the case of the Atacama Desert where precipitation is extremely scarce $(<20 \mathrm{~mm} / \mathrm{year}$, an order of magnitude lower than the samples studied by Helfenstein et al., 2018), this turnover time may be expected to be further inhibited, or P cycling completely retarded, unless biological communities can access less conventional forms of water to support nutrient cycling.
For example, organisms under hyperarid conditions are able to utilize hydration water from gypsum minerals to supplement the extremely scarce rain water (Palacio, Azorin, Montserrat-Marti, \& Ferrio, 2014).

This research aims to investigate the microbial $P$ utilization in the Atacama Desert and to examine the extent to which biological processing can overprint a mineral-dominated pool, even under the harshest of conditions. Previous studies using $\delta^{18} \mathrm{O}_{\mathrm{PO} 4}$ in Marsanalogous or arid terrestrial environments all focused on relatively water-rich locations. These studies suggested that $\delta^{18} \mathrm{O}_{\mathrm{PO} 4}$ values are sensitive to levels of enzymatic activity and microbial metabolism wherever liquid water might be present (Blake et al., 2001; Blake et al., 2005; Jaisi \& Blake, 2010). To improve interpretation of $\delta^{18} \mathrm{O}_{\mathrm{PO} 4}$ analyses, we performed soil metagenomic analyses and cell culture experiments: metagenomic analyses can provide information about the existence and relative abundance of P-processing enzymes and pathways to support isotopic findings, and cell culture experiments can indicate how microbes grow in soils of atypical C:N:P ratios and how they respond to bioavailable $\mathrm{P}$. Therefore, we combine this novel $\delta^{18} \mathrm{O}_{\mathrm{PO} 4}$ proxy for phosphorus cycling with enzyme pathway analyses and cell culture experiments to trace $P$ dynamics in soils spanning an aridity gradient from hyperarid to arid environments.

\section{MATERIALS AND METHODS}

\section{1 | Study site and soil characterizations}

The Atacama Desert is bounded by two high mountain ranges (the Coastal Cordillera and Altiplano/Andes Mountains) (Garreaud, Molina, \& Farias, 2010; Garreaud, Vuille, Compagnucci, \& Marengo, 2009; Houston \& Hartley, 2003; Rech et al., 2010; Veblen, Young, \& Orme, 2015), which prevent Pacific and Atlantic Ocean moisture from reaching the hyperarid core. Modern hyperaridity of the Atacama Desert is also a result of subtropical atmospheric subsidence (Takahashi \& Battisti, 2007), coupled with a temperature inversion caused by the interaction of the constant strong Pacific anticyclone (Trewartha, 1961) and coastal cold upwelling of the Humboldt ocean current (McKay et al., 2003). For this study, five sites were sampled on a latitudinal gradient from $22^{\circ} \mathrm{S}$ to $28^{\circ} \mathrm{S}$ (Figure 2). This sampling strategy was selected to provide an aridity gradient from hyperarid in the north to arid in the south (Figure 3); the sites are María Elena South (MES, 1,493 m altitude) (AzuaBustos, Caro-Lara, \& Vicuna, 2015), Point of No Return Dos (PONR2, 1,493 $\mathrm{m}$ altitude), Yungay (1,007 $\mathrm{m}$ altitude), Transition Zone 4 (TZ-4, 1,658 $\mathrm{m}$ altitude), and Transition Zone 5 (TZ-5, $588 \mathrm{~m}$ altitude), with 0-23 $\mathrm{mm}$ average annual precipitation estimated by Shen et al. (2019) shown in Table 1. We note that visual small plant vegetation appeared in TZ-4 and TZ-5, and dried grass roots appeared in their soil samples (Figure $3 \mathrm{~b}$ ). These locations had substantially less visible plant life when visited in 2012, suggesting that the strong rainfall events of 2015-2017 (Azua-Bustos et al., 2018; Uritskiy et al., 2019) might have stimulated a rare "desert bloom" at these locations prior to our sampling (Shen et al., 2019). 


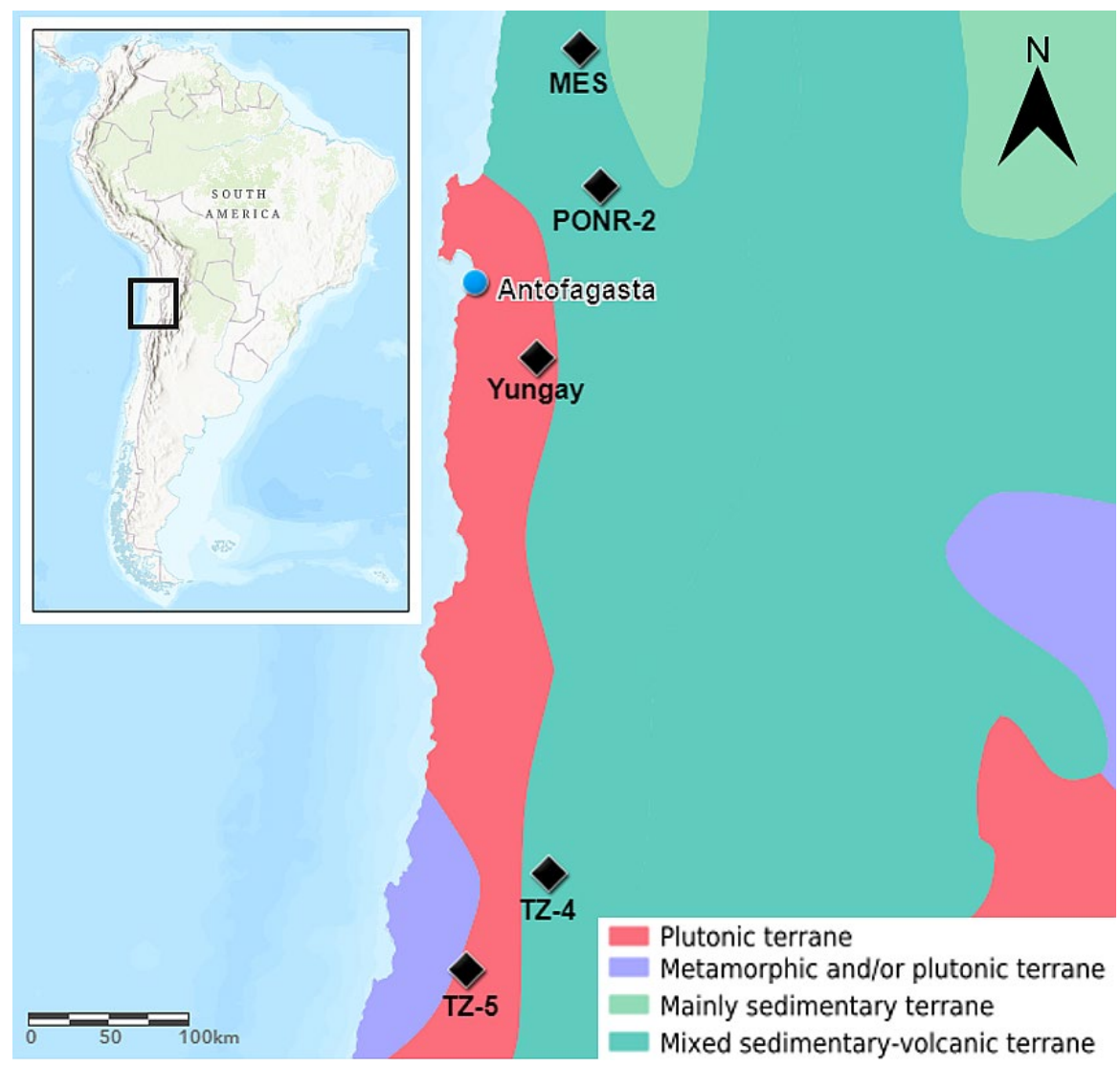

FIGURE 2 Geologic units (Kirkham et al. 1995) of five study sites (MES, María Elena South; PONR-2, Point of No Return Dos; TZ, Transition Zone)
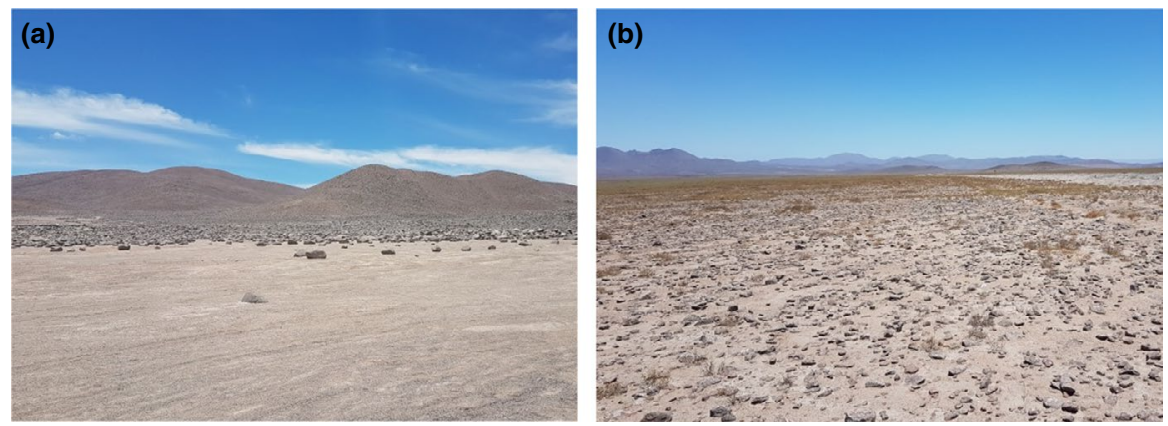

FIGURE 3 Landscapes of (a) hyperarid (MES) and (b) arid (TZ-4) sites of the Atacama Desert

TABLE 1 Altitude, mean annual temperatures, average precipitation, grain size, and pH from Shen et al. (2019) and C:N:P ratios (this study) of our five study sites. MES, PONR-2, and Yungay are from the hyperarid core; TZ-4 and TZ-5 are from the arid region

\begin{tabular}{|c|c|c|c|c|c|c|}
\hline Site & $\begin{array}{l}\text { Altitude (meter above sea } \\
\text { level } / \mathrm{m} \text { a.s.l.) }\end{array}$ & Temperature ${ }^{\circ} \mathrm{C}$ ) & $\begin{array}{l}\text { Precipitation }(\mathrm{mm} / \\
\text { year) }\end{array}$ & $\begin{array}{l}\text { Median grain size } \\
(\mu \mathrm{m})\end{array}$ & $\mathrm{pH}$ & $\mathrm{C}: \mathrm{N}: \mathrm{P}$ \\
\hline MES & 1493 & 21 & 0.7 & 444 & 8.38 & $128: 1: 7$ \\
\hline Yungay & 1007 & 17 & 2.0 & 464 & 8.11 & 610:1:4 \\
\hline TZ-4 & 1658 & 17 & 15.1 & 291 & 8.26 & $15: 1: 1$ \\
\hline
\end{tabular}

Briefly, MES, PONR-2, and TZ-4 are located on mixed sedimentary-volcanic terrane, while Yungay and TZ-5 are located on plutonic terrane (Figure 2). In detail, MES soils are fed by Quaternary and Jurassic sedimentary rocks, Mesozoic volcanics, and Mesozoic-Cenozoic plutonic rocks; PONR-2 soils form on
Quaternary sedimentary and Mesozoic volcanic rocks; Yungay soils form from Paleozoic-Mesozoic and Mesozoic-Cenozoic plutons, and Quaternary sedimentary rocks; TZ-4 soils form on a mixture of Cretaceous-Tertiary volcanics, Quaternary sediments, and Paleozoic-Mesozoic plutonic rocks; and TZ-5 soils are affected by 
Quaternary and Cretaceous sedimentary rocks, and PaleozoicCenozoic plutonic rocks (Schenk et al. 1999; Tapia et al., 2018).

Detailed sampling methods are described in Shen et al. (2019). In short, 3 pits were dug to $10-20 \mathrm{~cm}$ depth at each site, where $\sim 200 \mathrm{~g}$ of material was removed for geochemical analyses. From each study site, one of the pits was further sampled for $\delta^{18} \mathrm{O}_{\mathrm{PO} 4}$ analyses $(\sim 500 \mathrm{~g}$ of sediment), DNA extraction ( $50 \mathrm{~g})$, and cell spreading experiments $(\sim 100 \mathrm{~g})$ using sterile techniques. Soils of an additional TZ-5 pit that was surrounded by dead dried shrub, similar to all TZ-4 pits, were sampled for $\delta^{18} \mathrm{O}_{\mathrm{PO} 4}$ analyses. Samples were stored at $4^{\circ} \mathrm{C}$ to avoid any change in the microbial community structure and minimize microbial activity.

Mean annual precipitation and mean temperature (Table 1) for each sampling site were determined from the nearest meteorological stations between the years of 1951 and 2017, from Explorador Climático, Center for Climate and Resilience Research (available at: http://explorador.cr2.cl/). General soil properties ( $\mathrm{pH}$, electrical conductivity, total organic carbon (TOC), total organic nitrogen (TON), nitrate, grain sizes, and major elements in the regolith such as $\mathrm{P}_{2} \mathrm{O}_{5}$, $\mathrm{SiO}_{2}, \mathrm{Al}_{2} \mathrm{O}_{3}, \mathrm{MgO}$, and $\mathrm{Fe}_{2} \mathrm{O}_{3}$ ) were reported in Shen et al. (2019). Regolith $\mathrm{P}$ is referred to total $\mathrm{P}$ (TP). Carbonate from each sampling pit was determined in triplicate using the decarbonation method during the preparation step for TOC and TON measurements.

\section{2 | Sequential phosphate extraction}

Sequential extractions were undertaken on each soil sample to isolate different $\mathrm{P}$ pools of potential interest for $\delta^{18} \mathrm{O}_{\mathrm{PO} 4}$ analysis and P concentrations (Hedley, Stewart, \& Chauhan, 1982). Each bulk extraction started with large volumes of soil ( 100 g) in an attempt to ensure enough $\mathrm{P}$ was obtained for isotope purification and analysis, following Tamburini et al. (2010). Alongside this bulk method, we extracted a subsample of the soil using the same soil:solution ratios for concentration analysis. The concentrations of phosphate from each of the four extractable pools were quantified on an Aquahem 250 analyzer (Thermo Fisher Scientific) using a molybdenum blue reaction (Murphy \& Riley, 1962).

The stages of extraction followed Tamburini et al. (2018); briefly these were:

- Resin-extractable P (resin-P), extracted from approximately $600 \mathrm{~g}$ of soil in $3.6 \mathrm{~L}$ of $18.2 \mu \Omega$ ultrapure water with 3 pre-conditioned $125 \mathrm{~mm} \times 125 \mathrm{~mm}$ anion-exchange resin strips (VWR International Ltd). It should be noted that as these soils were extremely dry, there was a possibility that a water-based extraction would promote some rapid microbial response and release of $\mathrm{P}$ captured in this extraction. This is an unavoidable laboratory effect, but was mitigated as best possible by shaking at $4^{\circ} \mathrm{C}$ to limit microbial activity within the extract (Tamburini, Pistocchi, Helfenstein, \& Frossard, 2018).

- Microbial P, extracted from $100 \mathrm{~g}$ of fresh soil with $12.5 \mathrm{ml}$ of hexanol in $1 \mathrm{~L}$ of $18.2 \mu \Omega$ ultrapure water with one $125 \mathrm{~mm} \times 125$ $\mathrm{mm}$ pre-conditioned anion-exchange resin strip. This extraction captured the mixture of inorganic (resin- $\mathrm{P}$ as above) and microbial phosphate (Granger et al., 2018; Kouno, Tuchiya, \& Ando, 1995; Mclaughlin, Alston, \& Martin, 1986). Microbial P was calculated by subtracting resin-P from hexanol-extractable $P$.

- Oxide-bound and organic P pools were extracted using a $\mathrm{NaOH} /$ ethylenediaminetetraacetic acid (EDTA) mix $(6.5 \mathrm{mg} / \mathrm{ml} \mathrm{NaOH}$ and $12.0 \mathrm{mg} / \mathrm{ml}$ EDTA), added to hexanol extracted samples.

- $\mathrm{HCl}$-extractable $\mathrm{P}$ (Ca-P), $50 \mathrm{~g}$ of dried soil was added to $100 \mathrm{ml}$ of $1 \mathrm{M} \mathrm{HCl}$ (Tamburini, Bernasconi, Angert, Weiner, \& Frossard, 2010).

\section{$2.3 \mid \delta^{18} \mathrm{O}_{\mathrm{PO} 4}$ isotope analyses}

As we aimed to identify a long-lived biosignature of life in the Atacama sediments, we focused our $\delta^{18} \mathrm{O}$ analyses on the most stable P pool, Ca-P. Phosphate in these extracts was converted to $\mathrm{Ag}_{3} \mathrm{PO}_{4}$ using a slightly adapted purification protocol described by Tamburini et al (2010). Briefly, phosphate was precipitated as ammonium phospho-molybdate (APM) at a $\mathrm{pH}$ of 1 (ensured with the addition of $1 \mathrm{ml}$ of concentrated sulfuric acid) and then dissolved in $\mathrm{NH}_{4}$-citrate solution and re-precipitated as magnesium ammonium phosphate (MAP). The MAP precipitate was further dissolved in $\mathrm{HNO}_{3}$ and shaken with cation resin (AG $508 \mathrm{X}$ ). The phosphate in solution was converted to $\mathrm{Ag}_{3} \mathrm{PO}_{4}$ by adding $7 \mathrm{ml}$ of $\mathrm{Ag}$-ammine solution, and the precipitate was oven-dried at $50^{\circ} \mathrm{C}$. This method does not use the DAX-8 resin step of Tamburini et al (2010) as this is not necessary unless organic contamination is present in the subsequent $\mathrm{Ag}_{3} \mathrm{PO}_{4}$ (Granger et al., 2018).

Analysis of $\delta^{18} \mathrm{O}_{\mathrm{PO} 4}$ was undertaken by weighing approximately $300 \mu \mathrm{g}$ of $\mathrm{Ag}_{3} \mathrm{PO}_{4}$ into a silver capsule, this sample was then converted to carbon monoxide ( $\mathrm{CO}$ ) using a thermal conversion elemental analyzer (TC-EA, Thermo Finnigan) at $1,400^{\circ} \mathrm{C}$ in the presence of glassy carbon chips. The product $\mathrm{CO}$ mixed with a helium carrier gas and was analyzed on a Delta $+\mathrm{XL}$ mass spectrometer (Thermo Finnigan) at the British Geological Survey (UK). The $\delta^{18} \mathrm{O}_{\mathrm{PO} 4}$ values were calculated by comparison to an internal $\mathrm{Ag}_{3} \mathrm{PO}_{4}$ standard, ALFA-1 (ALFA-1 $=\delta^{18}$ O VSMOW value of $+14.2 \%$ ). In the absence of an international $\mathrm{Ag}_{3} \mathrm{PO}_{4}$ reference material, the value for ALFA- 1 is derived by comparison to the $\mathrm{Ag}_{3} \mathrm{PO}_{4}$ standard "B2207" (Elemental Microanalysis Ltd., England), which has been measured in an inter-laboratory comparison study to have a $\delta^{18} \mathrm{O}$ value of $+21.7 \%$ versus VSMOW. Samples were run in triplicate, with a typical precision $\sigma \leq 0.4 \%$. Sample purity was assessed by determining the $\mathrm{CO}$ yield compared with the yield of $\mathrm{Ag}_{3} \mathrm{PO}_{4}$ standards and rejecting samples where this differed by $10 \%$.

\section{4 | Metagenomic extraction, sequencing, and enzyme/pathway predictions}

To understand the microbial pathways in P dynamics, we performed soil metagenomic analyses. All implementations for gene experiments were either filter-sterilized, autoclaved, or UV-irradiated 
to prevent any external contamination; water was molecular biology grade and nuclease-free. DNA of MES, PONR-2, Yungay, TZ-4, and TZ-5 was extracted with one negative control using the FastDNA ${ }^{\mathrm{TM}}$ SPIN Kit for Soil (MP Biomedicals) following a modified manufacturer's protocol: During the cell lysis step, mixtures were incubated at room temperature for $1 \mathrm{hr}$. DNA extracts were amplified for barcoded Illumina $16 \mathrm{~S}$ metagenomic sequencing using KAPA HiFi HotStart ReadyMix (KAPA Biosystems) and 16S rRNA primer pair 341F, 5'-CCTACGGGNGGCWGCAG-3', and 785R, 5'-GACTACHVGGGTATCTAATCC-3' (Herlemann et al., 2011; Klindworth et al., 2013). Amplicon concentration was quantified using a Qubit ${ }^{\text {TM }}$ 3.0 Fluorometer (Invitrogen). The index PCR thermocycling was conducted using Nextera index kit (Illumina $\left.{ }^{\circledR}\right)$, and only samples with sufficient yields, namely MES, TZ-4, and TZ-5, were passed for further preparation of sequencing. 16S rRNA gene amplicons for Illumina MiSeq System were prepared and sequenced using paired-end $300 \mathrm{bp}$ reads with v3 Chemistry by following the $16 \mathrm{~S}$ Metagenomic Sequencing Library Preparation protocol (Illumina ${ }^{\circledR}$ ) alongside a $20 \%$ PhiX control, slightly modified by extending the amplicon PCR from 25 to 29 cycles.

Bacterial sequences were analyzed by the open-source program Quantitative Insights into Microbial Ecology 2 (QIIME 2) (Bolyen et al., 2019). Illumina-sequenced paired reads were combined and demultiplexed into Casava 1.8 paired-end format. Reads of low quality and chimeric sequences were removed with DADA2 (Callahan et al., 2016). Reads were filtered by trimming the first 13 base pairs and of a length less than 300 base pairs. Total sequences were clustered into operational taxonomic units (OTUs) at 99\% identity and filtered through chimera checking using VSEARCH (Rognes, Flouri, Nichols, Quince, \& Mahe, 2016) and UCHIME (Edgar, Haas, Clemente, Quince, \& Knight, 2011). The representative taxonomic identities were aligned at $99 \%$ full-length sequence similarity using pre-trained SILVA 132 16S rRNA marker gene reference database (Quast et al., 2013).

Potential functions of these $16 \mathrm{~S}$ sequences were predicted with Phylogenetic Investigation of Communities by Reconstruction of Unobserved States 2 (PICRUSt2) (Douglas et al., 2019). Briefly, reads were assigned into phylogenetic units with HMMER (Eddy \& Wheeler, 2007; Johnson, Eddy, \& Portugaly, 2010), EPA-ng (Barbera et al., 2019), and GAPPA (Czech \& Stamatakis, 2019). The hidden-state prediction was performed with the $\mathrm{R}$ package caster (Louca \& Doebeli, 2018). Finally, microbial enzymes and metabolic pathways were identified using the Minimal set of Pathways (MinPath) approach (Ye \& Doak, 2009) referencing the MetaCyc pathway database (Caspi et al., 2016; Caspi et al., 2018).

Here, we focused only on data pertaining to biogeochemical P dynamics in the sampled soils, as it was beyond the scope of this study to provide a full metagenomic dataset. Enzymes and metabolic pathways related to microbial phosphate dynamics were selected from all records of predicted pathways. The abundance of phosphate-involved pathway copy numbers was plotted with OriginPro 2019 (OriginLab Corporation).

\section{5 | Phosphate amendments and cell culture experiments}

To explore the microbial growth in these extremely dry soils of atypical C:N:P ratios, we performed cell culture experiments and phosphate amendments. About $10 \mathrm{~g}$ of soil from each sampling site was amended with $4.5 \mathrm{ml}$ sterilized $10 \%$ monosodium phosphate $\left(\mathrm{NaH}_{2} \mathrm{PO}_{4}\right)$ and $4.5 \mathrm{ml}$ sterilized ultrapure water (as a control) and left for 4 days at room temperature (Shen et al., 2019). Soils were then refrigerated at $4^{\circ} \mathrm{C}$. Duplicate amended soils and original soils without amendment were suspended in sterilized ultrapure water by an applicable dilution factor and spread on Luria-Bertani (LB) agar and plate count agar plates, and left at $21^{\circ} \mathrm{C}$. Colonies were counted after 20 days of growth (Bagaley, 2006). Colony-forming units (CFUs) were calculated by multiplying the number of colonies formed on agar plates by the correspondent dilution factor, and a factor 1.45 to account for the addition of $4.5 \mathrm{ml}$ solution to $10 \mathrm{~g}$ of soil. CFUs on phosphate amendments were further transformed into logarithmic scale, and normalized as the difference relative to water only amendments.

\section{3 | RESULTS}

\subsection{Nutrients, mafic elements, and $\delta^{18} \mathrm{O}_{\mathrm{PO} 4}$}

We saw no correlation between TOC and TP at the hyperarid core, and the TOC and TP of arid sites were both higher than hyperarid sites (Figure $5 \mathrm{a}$ ). The $\mathrm{P} / \mathrm{N}$ ratio anticorrelated with TOC, with 4 of the 5 sites showing a distinctive relationship. However, site TZ-5 (the wettest site) displayed a different decreasing trend from the other four sites (Figure $5 \mathrm{~b}) . \mathrm{P} / \mathrm{N}$ significantly correlated $\left(R^{2}=0.88^{* * *}\right.$ and $p=.000$ ) with $\mathrm{SiO}_{2} / \mathrm{Al}_{2} \mathrm{O}_{3}$ (used to approximate quartz to clay ratios (Broadhurst \& Loring, 1970; Olivares et al. 2017; Xiao, Porter, An, Kumai, \& Yoshikawa, 1995)) (Figure 5c), which was generally taken as a proxy of sedimentation rates. Additionally, sites with lower levels of total P commonly had larger grain sizes (Table 1).

$\mathrm{Mg}$ and Fe were two common mafic elements, the richness of which indicated the abundance of igneous rock sources (Barker, 1978). $\mathrm{MgO}$ in the sediments of sampling sites ranged from 0.9 to $1.4 \%$ in hyperarid sites, and was higher in arid sites, from 2.2 to $3.3 \%$. $\mathrm{Fe}_{2} \mathrm{O}_{3}$ ranged from 2.8 to $4.3 \%$ in hyperarid sites, and was still higher in arid sites, between 5.2 and 6.6\% (Table 2). $\mathrm{Fe}_{2} \mathrm{O}_{3}$ (\%) had a linear relationship with $\mathrm{MgO}$ (Figure $5 \mathrm{~d}$ ).

\subsection{Distribution of different $\mathbf{P}$ pools}

Compared to the hyperarid sites (MES, PONR-2, and Yungay, $<2 \mathrm{~mm} /$ year), arid sites (TZ-4 and TZ-5, 15-20 mm/year) had a greater pool size of microbial $\mathrm{P}$ and $\mathrm{NaOH}-\mathrm{P}$ (including $\mathrm{Al} / \mathrm{Fe}$ oxide-bound $\mathrm{P}$ and organic $\mathrm{P}$ ), but a relatively smaller pool size of resin- $\mathrm{P}$ and $\mathrm{HCl}-\mathrm{P}$ (usually calcium-bound $\mathrm{P}$, hereafter noted as $\mathrm{Ca}-\mathrm{P}$ ) (Figure 4). Microbial $\mathrm{P}$ 

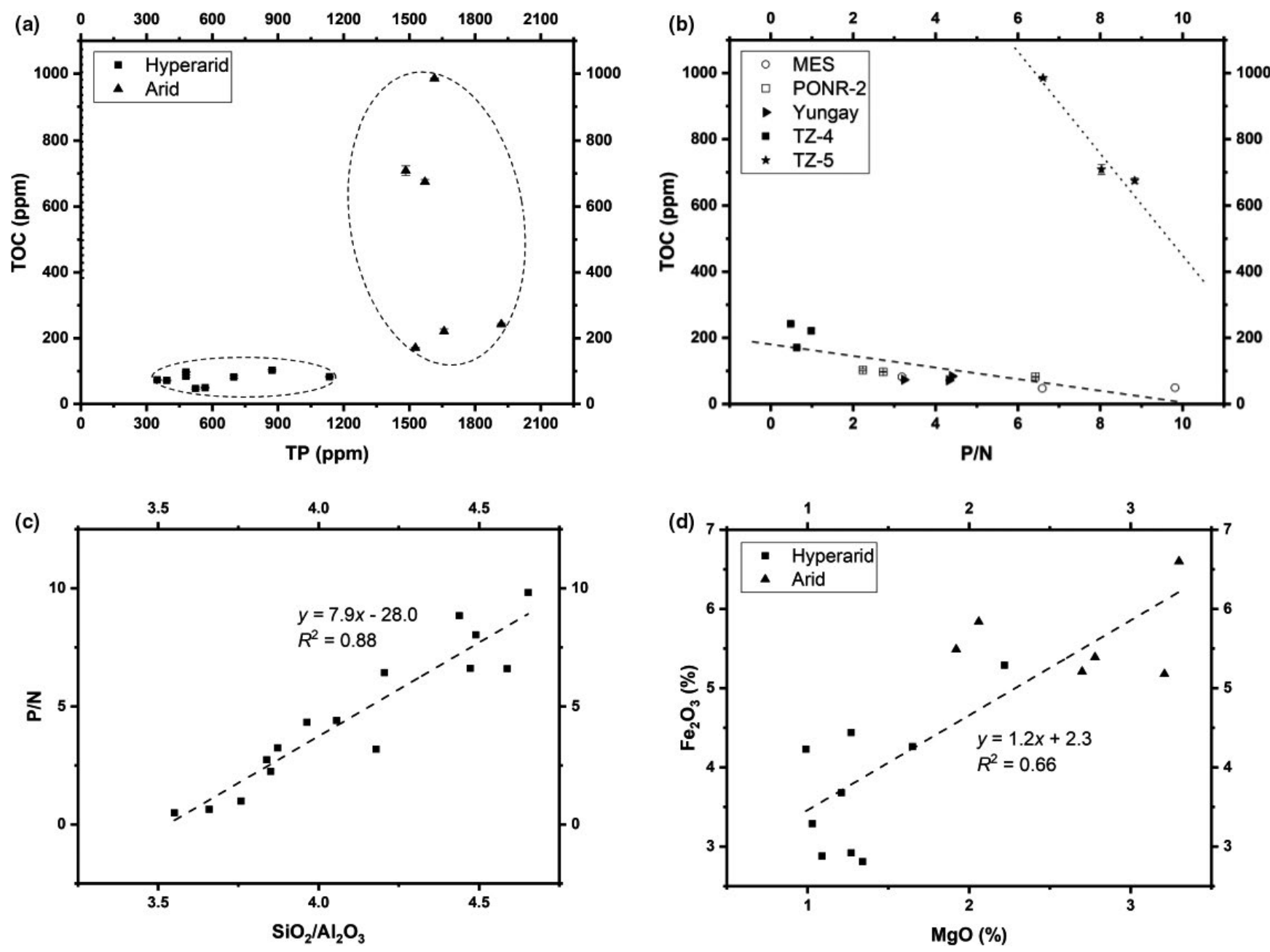

FIGURE 5 Cross plots for soil geochemical data (a) TOC versus TP; (b) TOC versus P/N; (c) P/N versus silicon to aluminum content; and (d) iron versus magnesium content

TABLE 2 Stable oxygen isotope ratios of phosphate, and proportions of $\mathrm{MgO}$ and $\mathrm{Fe}_{2} \mathrm{O}_{3}$ in sediments from sampled sites. Isotopic data here show mean \pm standard error. The standard deviations of $\mathrm{MgO}$ and $\mathrm{Fe}_{2} \mathrm{O}_{3}$ are between 0.01 and $0.05 \%$ based on precision analyses of X-ray fluorescence standards (Shen et al., 2019)

\begin{tabular}{lrll} 
Site & $\boldsymbol{\delta}^{18} \mathrm{O}_{\mathrm{PO} 4}(\%)$ & $\mathrm{MgO}(\%)$ & $\begin{array}{l}\mathrm{Fe}_{2} \mathrm{O}_{3} \\
(\%)\end{array}$ \\
\hline MES & $7.90 \pm 0.17$ & 1.34 & 2.81 \\
\hline PONR-2 & $13.62 \pm 0.17$ & 1.03 & 3.29 \\
\hline Yungay & $11.18 \pm 0.18$ & 0.99 & 4.23 \\
\hline TZ-4 & $19.93 \pm 0.34$ & 3.30 & 6.60 \\
\hline TZ-5 & $25.10 \pm 0.16$ & 2.70 & 5.21 \\
\hline TZ-5-shrub & $22.02 \pm 0.17$ & 2.23 & 5.51 \\
\hline
\end{tabular}

positively correlated with $\mathrm{NaOH}-\mathrm{P}\left(R^{2}=0.88^{*}, p=.022\right)$. In addition, sites with smaller microbial $\mathrm{P}$ and $\mathrm{NaOH}-\mathrm{P}$ pools generally had larger grain sizes (Table 1). Plots of microbial $P$ and total $P$ clustered together within hyperarid and arid sites (Figure 6a). The $\delta^{18} \mathrm{O}_{\mathrm{PO} 4}$ values of soil Ca-P from the hyperarid sites (MES, PONR-2, and Yungay) varied between 7.7 and 13.8\%, and from arid sites (TZ-4 and TZ-5) between 19.5 and $25.3 \%$ (Table 2). The contents of TOC, TON, and microbial P correlated with the $\delta^{18} \mathrm{O}_{\mathrm{PO} 4}$ of $\mathrm{Ca}-\mathrm{P}$ (Figure $6 \mathrm{~b}-\mathrm{d}$ ).

\subsection{Enzymes and pathways in microbial phosphate metabolisms}

The overall structure of the relative abundance of phosphate pathways in MES, TZ-4, and TZ-5 was very similar (Figure 7). The least abundant pathways were sucrose degradation IV, glucose and glucose-1-phosphate degradation, Entner-Doudoroff pathway III (sugar degradation), UDP-2,3-diacetamido-2,3-dideoxy- $\alpha$-D-mannuronate biosynthesis, CMP-legionaminate biosynthesis I (sugar-nucleotide synthesis), pyrimidine deoxyribonucleotides de novo biosynthesis IV, pyrimidine deoxyribonucleotides biosynthesis from CTP (nucleotide synthesis), and phospholipases. Comparatively, the microbiome of MES was more abundant in GDP-mannose biosynthesis, GDP-mannose-derived O-antigen building blocks biosynthesis 


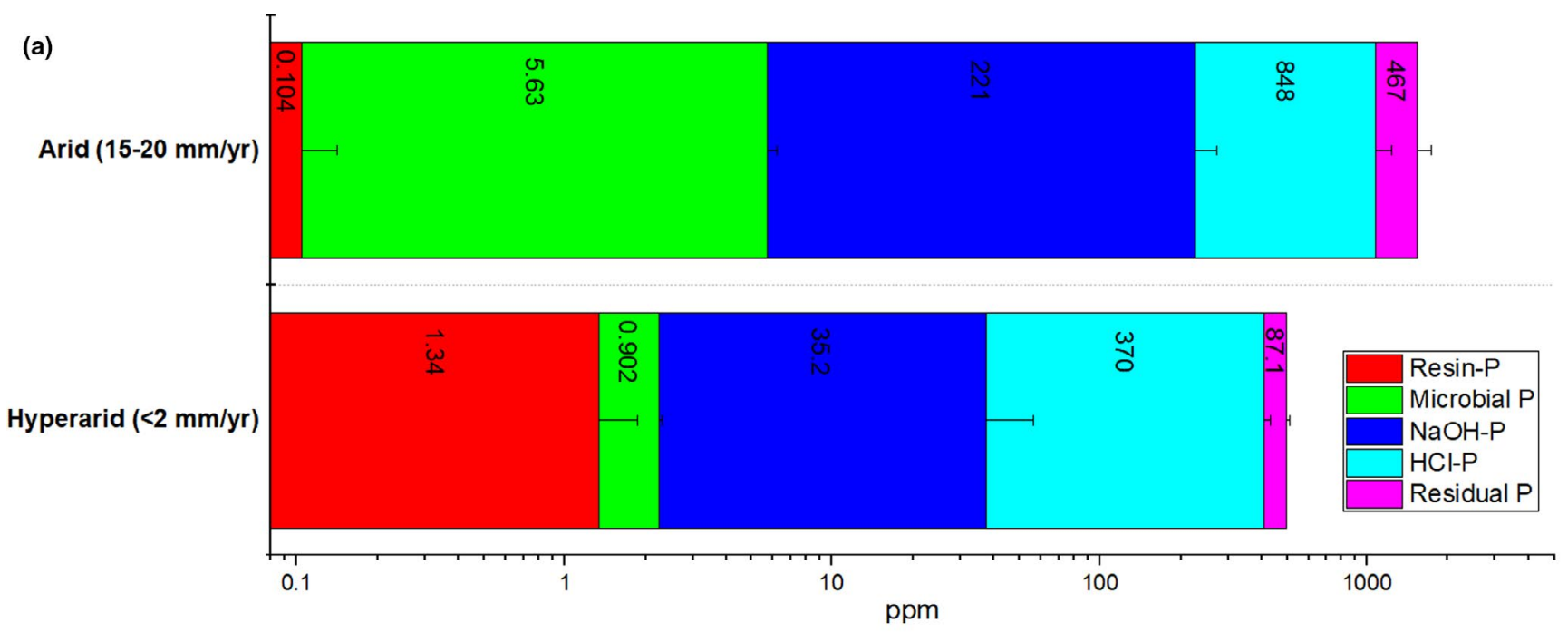

(b)

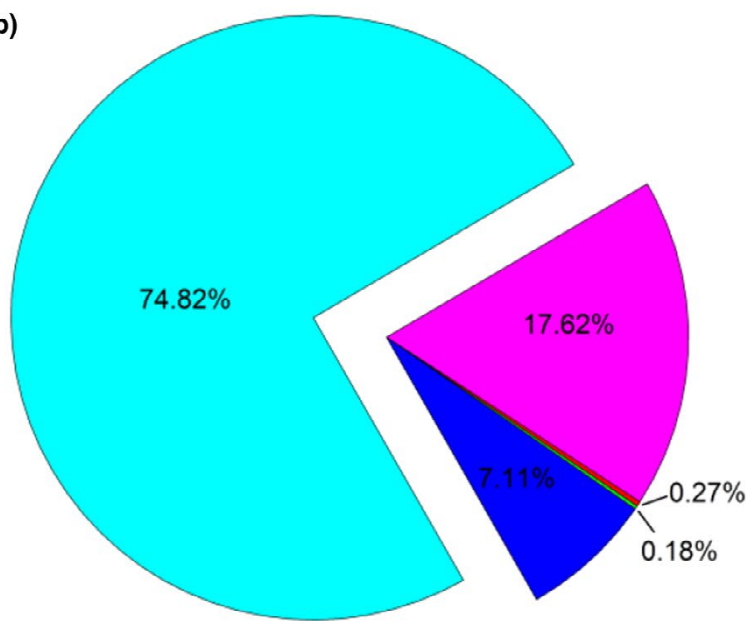

(c)

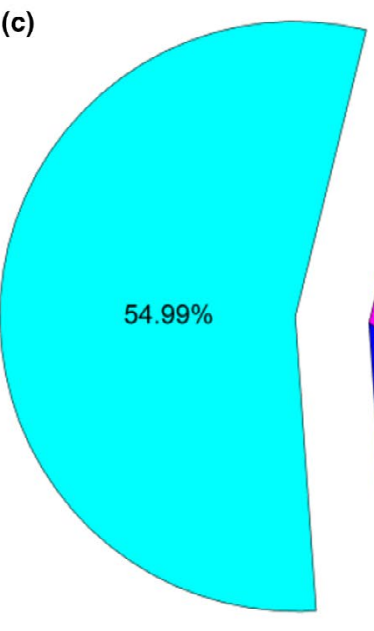

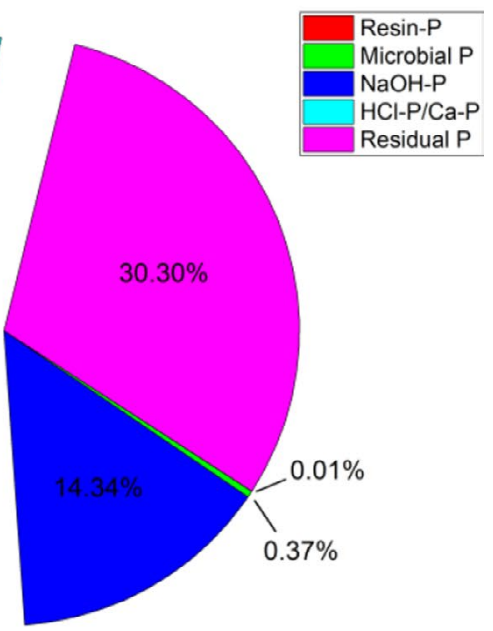

FIGURE 4 (a) Absolute pool sizes and (b and c) relative pool sizes of resin-extractable P, microbial P, NaOH-extractable P, HClextractable $\mathrm{P}(\mathrm{Ca}-\mathrm{P})$, and the residual $\mathrm{P}$ in (b) hyperarid sites and $(\mathrm{c})$ arid sites

(sugar-nucleotide synthesis), pyrimidine deoxyribonucleotides de novo biosynthesis III (nucleotide synthesis), ketogluconate metabolism (sugar acid degradation), pyridoxal 5'-phosphate biosynthesis and salvage (vitamin synthesis), and tRNA processing. The TZ-4 microbiome was abundant in all pathways but ketogluconate metabolism (sugar acid degradation), pyridoxal 5'-phosphate biosynthesis and salvage, thiamin diphosphate biosynthesis II (vitamin synthesis), S-methyl-5-thio- $\alpha$-D-ribose 1-phosphate degradation (nucleotide degradation), pyrimidine deoxyribonucleotides de novo biosynthesis II, and purine nucleotides de novo biosynthesis II (nucleotide synthesis). The TZ-5 microbiome was abundant in all pathways but tRNA processing, GDP-mannose biosynthesis (sugar-nucleotide synthesis), GDP-mannose-derived O-antigen building blocks biosynthesis, and pyrimidine deoxyribonucleotides de novo biosynthesis III (nucleotide synthesis).

The copy number of inorganic pyrophosphatase genes increased from $\sim 50,000$ in MES to $\sim 70,000$ in the two arid sites (TZ-4 and TZ-5). Alkaline phosphatase genes increased from $\sim 14,000$ in MES to $\sim 30,000$ in arid sites. Both DNase and RNase genes increased from $\sim 160,000$ in MES to $\sim 250,000$ in arid sites. The abundance of acid phosphatase and 5'-nucleotidase genes were $\sim 4,000$ and $\sim 40,000$ in these three sites, respectively. Phytase genes increased from $\sim 300$ in MES to $\sim 2,000$ in arid sites (Table 3).

\subsection{Microbial growth with phosphate amendments}

Cultivable heterotrophic micro-organisms from the hyperarid sites and the drier arid site TZ-4 universally did not prefer growing on excessive bioavailable inorganic phosphate. However, the cultivable microbial communities of site TZ-5 did seem to display a preference for growth on phosphate amended plates (Tables 4 and 5). 

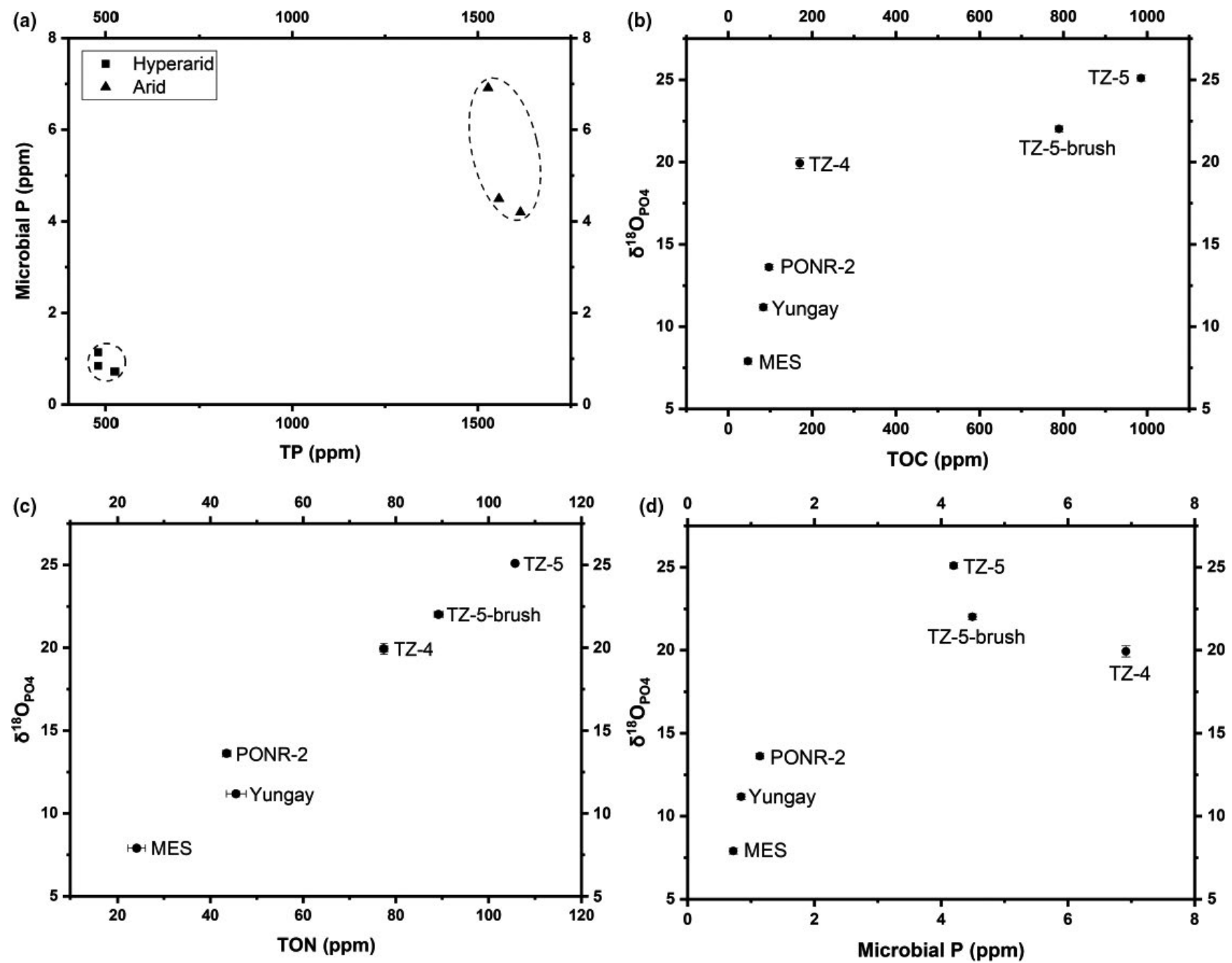

FIGURE 6 Cross plots for soil geochemical data (a) $\delta^{18} \mathrm{O}_{\mathrm{PO} 4}$ versus microbial P; $\delta^{18} \mathrm{O}_{\mathrm{PO} 4}$ of Ca-P versus (b) TOC, (c) TON, and (d) microbial $P$

\section{4 | DISCUSSION}

\section{1 | Phosphorus distribution and microbial P cycling in Atacama sediments}

In hyperarid environments such as the core of the Atacama Desert, $\mathrm{P}$ loss induced by leaching is negligible; hence, phosphate can be preserved to high levels in sediments. Release of inorganic $P$ in desert minerals can be stimulated via chemical weathering (Sheldon, 1982) and by various microbial solubilization mechanisms, usually including acidification by 2-ketogluconic acid and chelation of the cations bound to P (Ameen et al., 2019; Osorio \& Habte, 2013; Scervino et al., 2010; Sharma, Sayyed, Trivedi, \& Gobi, 2013). During longterm aridity, phosphate can be released by microbial death and plant decay, for example, after an episodic rainfall-led desert bloom event (Fabre, Gauquelin, Vilasante, Ortega, \& Puig, 2006; Orlando, Alfaro, Bravo, Guevara, \& Caru, 2010; Vidiella, Armesto, \& Gutierrez, 1999). Although $\mathrm{Ca}-\mathrm{P}$ can dissolve abiotically, this process is negligible when $\mathrm{pH}$ is more than 8 (Guidry \& Mackenzie, 2003) (Table 1).
At these high levels of phosphorus (with $C: P$ of $67: 1$ on average) in spite of a large portion of $\mathrm{Ca}-\mathrm{P}$, micro-organisms in Atacama soils might be less phosphorus-limited than in normal terrestrial soils, where C:P is typically $186: 1$ on average (Cleveland \& Liptzin, 2007; Reed \& Wood, 2016). We also see that the addition of inorganic $P$ to cell culture experiments makes no positive impact on the colony-forming units (CFU) for all of the sites with rainfall below $15 \mathrm{~mm}$ /year (MES, PONR-2, Yungay, TZ-4; Table 5). However at TZ-5, where annual precipitation levels can be $20 \mathrm{~mm}$ or more, addition of phosphate to the agar plates enhances growth. Therefore, it appears that $\mathrm{P}$ can once again become a limiting nutrient at higher precipitation levels, even though the $\mathrm{C}: \mathrm{N}: \mathrm{P}$ ratio (258:1:5) still suggests a remarkably greater $\mathrm{P}$ reserve than $\mathrm{N}$ compared to normal terrestrial soils (186:13:1) (Cleveland \& Liptzin, 2007; Reed \& Wood, 2016). When amended with excess inorganic phosphate, growth of microbial colonies from TZ-5 increases significantly, by about 2 orders of magnitude (Table 5). However, the phosphate salts used in this amendment are directly available for biochemical use, quite different than the major pool of $\mathrm{P}$ at TZ-5, 
Pathway

5-aminoimidazole ribonucleotide biosynthesis I 5-aminoimidazole ribonucleotide biosynthesis II 6-hydroxymethyl-dihydropterin diphosphate biosynthesis I 6-hydroxymethyl-dihydropterin diphosphate biosynthesis III (Chlamydia) adenosine deoxyribonucleotides de novo biosynthesis II adenosine nucleotides degradation 1 adenosine ribonucleotides de novo biosynthesis ADP-L-glycero- $\beta$-D-manno-heptose biosynthesis CDP-diacylglycerol biosynthesis I CMP-3-deoxy-D-manno-octulosonate biosynthesis ICMP-legionaminate biosynthesis IdTDP-L-rhamnose biosynthesis IdTDP-N-acetylthomosamine biosynthesis Entner-Doudoroff pathway III (semi-phosphorylative)GDP-D-glycero- $\alpha$-D-manno-heptose biosynthesis GDP-mannose biosynthesis glucose and glucose-1-phosphate degradationglycogen biosynthesis I (from ADP-D-Glucose) glycolysis I (from glucose 6-phosphate) glycolysis II (from fructose 6-phosphate

guanosine deoxyribonucleotides de novo biosynthesis guanosine nucleotides degradation III

guanosine ribonucleotides de novo biosynthesis inosine-5'-phosphate biosynthesis I inosine-5'-phosphate biosynthesis III ketogluconate metabolism methylerythritol phosphate pathway I methylerythritol phosphate pathway II-

methylphosphonate degradation mono-trans, poly-cis decaprenyl phosphate biosynthesis pentose phosphate pathway pentose phosphate pathway (non-oxidative branch) phosphatidylglycerol biosynthesis I (plastidic) phosphatidylglycerol biosynthesis II (non-plastidic) phospholipases phosphopantothenate biosynthesis purine nucleotides degradation II (aerobic) pyridoxal 5'-phosphate biosynthesis pyrimidine deoxyribonucleotide phosphorylation pyrimidine deoxyribonucleotides biosynthesis from CTP pyrimidine deoxyribonucleotides de novo biosynthesis Ipyrimidine deoxyribonucleotides de novo biosynthesis II pyrimidine deoxyribonucleotides de novo biosynthesis IIIpyrimidine deoxyribonucleotides de novo biosynthesis IV -

S-methyl-5-thio-a-D-ribose 1-phosphate degradation sucrose degradation IV (sucrose phosphorylase) superpathway of 5-aminoimidazole ribonucleotide biosynthesissuperpathway of adenosine nucleotides de novo biosynthesis Isuperpathway of adenosine nucleotides de novo biosynthesis II superpathway of GDP-mannose-derived O-antigen building blocks biosynthesis superpathway of geranylgeranyl diphosphate biosynthesis II (via MEP) superpathway of geranylgeranyldiphosphate biosynthesis I (via mevalonate) superpathway of guanosine nucleotides de novo biosynthesis superpathway of guanosine nucleotides de novo biosynthesis II superpathway of phospholipid biosynthesis I (bacteria) superpathway of purine nucleotides de novo biosynthesis superpathway of purine nucleotides de novo biosynthesis II superpathway of pyridoxal 5'-phosphate biosynthesis and salvage superpathway of pyrimidine deoxyribonucleotides de novo biosynthesis superpathway of pyrimidine deoxyribonucleotides de novo biosynthesis (E. coli) superpathway of pyrimidine ribonucleotides de novo biosynthesis superpathway of thiamin diphosphate biosynthesis Isuperpathway of thiamin diphosphate biosynthesis II superpathway of UDP-glucose-derived O-antigen building blocks biosynthesis superpathway of UDP-N-acetylglucosamine-derived O-antigen building blocks biosynthesis -

tRNA charging tRNA processing

UDP-2,3-diacetamido-2,3-dideoxy- $\alpha$-D-mannuronate biosynthesis UDP-N-acetyl-D-glucosamine biosynthesis I UDP-N-acetylmuramoyl-pentapeptide biosynthesis I (meso-diaminopimelate containing) UDP-N-acetylmuramoyl-pentapeptide biosynthesis II (lysine-containing) UMP biosynthesis urate biosynthesis/inosine 5'-phosphate degradation CDP-diacylglycerol biosynthesis II -

\section{Abundance}

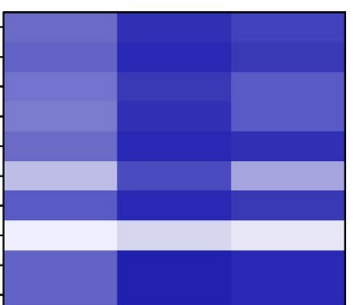

(2)
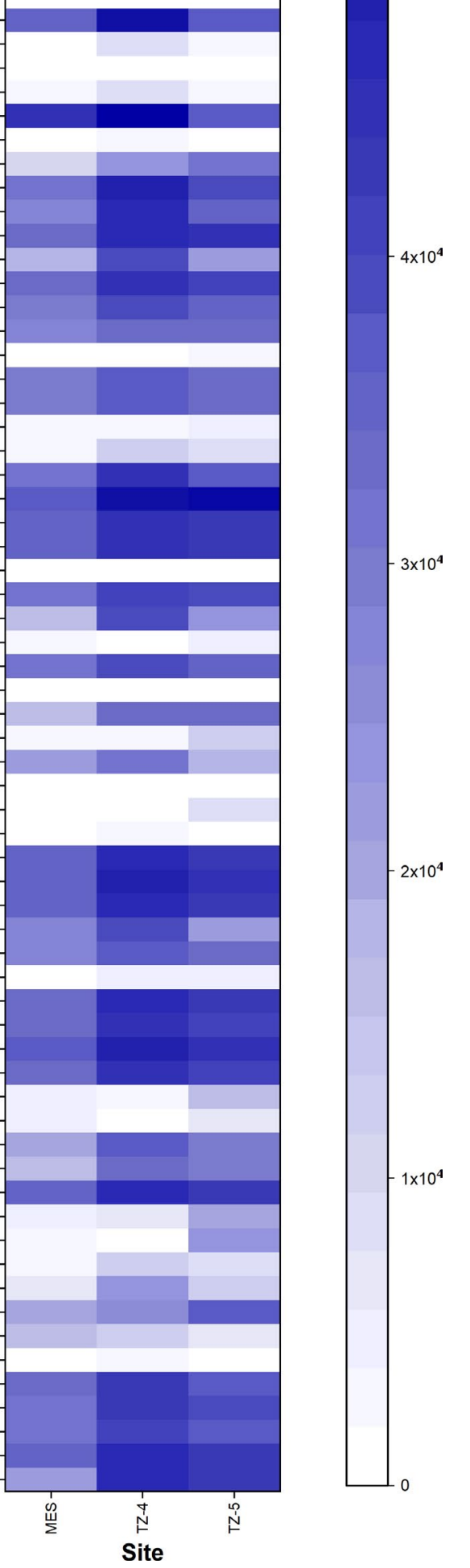

FIGURE 7 Predicted pathways related to biological phosphate metabolisms. Degradation pathways are shown in boxes 
TABLE 3 Numbers of predicted genes for enzymes related to $P$ dynamics

\begin{tabular}{|lrrr|}
\hline Enzyme abundance & MES & \multicolumn{1}{c}{ TZ-4 } & \multicolumn{1}{c}{ TZ-5 } \\
\hline Inorganic pyrophosphatase & 45955 & 76683 & 67800 \\
\hline Alkaline phosphatase & 14093 & 34644 & 29382 \\
\hline Acid phosphatase & 3371 & 4440 & 2734 \\
\hline DNase & 156246 & 287174 & 248682 \\
\hline RNase & 172222 & 225415 & 232564 \\
\hline 5'-nucleotidase & 33595 & 51364 & 40615 \\
\hline Phytase & 305 & 3105 & 1343 \\
\hline
\end{tabular}

which is in the form of Ca-P (Figure 4). This trend indicates that biological activity at the least arid site is limited by resin-P even if $P$ reserves in the form of $\mathrm{Ca}-\mathrm{P}$ are present.

Various $\mathrm{P}$ sources can be accessed by microorganisms via immobilization, mineralization, and biological solubilization (Gyaneshwar, Kumar, \& Parekh, 1998; Illmer \& Schinner, 1992; Nahas, 1996) (Figure 1). It appears that these processes must occur to some extent for our sites, as at higher TP levels, we observe that microbial P pool size is also greater (Figure 6a). This trend is also consistent with the transition from hyperarid to arid sites recorded by the relationship between TOC and TP (Figure 5a). These correlations indicate that when rainfall exceeds $\sim 10 \mathrm{~mm} /$ year, some TP can be desorbed by biological solubilization and made bioavailable by native microorganisms in situ. Accordingly, the microbial communities could be utilizing mineral $\mathrm{P}$ at TZ-5, but at a much slower pace than the resin-P which was added in the cell culture experiments, hence the hundred-fold increase in colony development (Table 5). This reasoning highlights the possibility for resin- $P$ limitation even where mineral $P$ may be more plentiful than other key nutrients such as nitrogen, and at a site where mineral $\mathrm{P}$ breakdown appears to be dominated by biological solubilization.

In all other sites, excessive phosphate amendment displays a detrimental effect on microbial growth (Table 5), contrary to the general eutrophication response seen in most natural environments (Golterman, 1973; Lucassen, Smolders, Lamers, \& Roelofs, 2005) (Table 5). Usually, the species that actively react to phosphate eutrophication are members of aquatic phytoplankton (Chislock, Doster, Zitomer, \& Wilson, 2013; Schindler
\& Vallentyne, 2008; Vangeel, Mur, Ralskajasiewiczowa, \& Goslar, 1994), which are different from extremophiles in desert ecosystems. The unusually high soil $\mathrm{P} / \mathrm{N}$ ratios are a result of the low $\mathrm{N}$ availability (Shen et al., 2019) as limited by water discharge and weathering (Mclsaac, David, Gertner, \& Goolsby, 2001; Schindler \& Vallentyne, 2008; Smolders, Lucassen, Bobbink, Roelofs, \& Lamers, 2010; Vitousek, Porder, Houlton, \& Chadwick, 2010; Walker \& Syers, 1976). When P/N ratios are more than 1 (Table 1), TOC is negatively associated with $\mathrm{P} / \mathrm{N}$ ratios (Figure $5 \mathrm{~b}$ ). This result suggests that high ambient $\mathrm{P} / \mathrm{N}$ ratios can be unfavorable to microbial communities in an extremely dry environment. In effect, $\mathrm{N}$ sources can conversely promote microbial utilization of $\mathrm{P}$, and nitrate is undoubtedly the major $\mathrm{N}$ source in the Atacama Desert (Michalski, Bohlke, \& Thiemens, 2004). Only sufficient nitrate can enhance the availability of phosphate by oxidizing ferrous iron, which inhibits iron-phosphate interaction (Smolders et al., 2010). Thus at low N/P (namely high $\mathrm{P} / \mathrm{N}$ ) ratios, the nitrate-driven promotion of microbial $\mathrm{P}$ utilization is reduced, which is further unfavorable to microbial communities.

Along the hyperarid to arid gradient, the proportion of resin- $\mathrm{P}$ from Atacama soils decreases (Figure 4) as it is presumably immobilized by the more abundant microbial communities in arid sites (Figure 1), although the concentrations of resin-P from Atacama soils are approaching the detection limit for our method (Crain, McLaren, Brunner, \& Darrouzet-Nardi, 2018; Lester, Satomi, \& Ponce, 2007). Similarly, the relative sizes of microbial $\mathrm{P}$ and $\mathrm{NaOH}-\mathrm{P}$ pools increase in arid sites (Figure 4). Besides the impact of rainfall on microbial $P$ and $\mathrm{NaOH}-\mathrm{P}$ (as containing organic $\mathrm{P}$ ) pools, sedimentation potentially plays an important role in diluting these $P$ pools, since the higher microbial $\mathrm{P}$ and $\mathrm{NaOH}-\mathrm{P}$ levels are associated with smaller grain size (Table 1) and higher $\mathrm{SiO}_{2} / \mathrm{Al}_{2} \mathrm{O}_{3}$ (quartz to clay ratios) (Figure $5 \mathrm{c}$ ) in our study sites. Usually, larger grain sizes cause a decline in the sorption rates of phosphate in organic form (Meng, Yao, \& Yu, 2014). Similarly, we recently postulated that bulk $\mathrm{N}$ concentrations, largely supplied as nitrate by atmospheric deposition (Ewing et al., 2007; Michalski et al., 2004), could be diluted by higher sedimentation rates and thus more limited to microorganisms (Shen et al., 2019). High sedimentation rates thus promote higher $\mathrm{P} / \mathrm{N}$ ratios and a small relative pool size of microbial $\mathrm{P}$ and $\mathrm{NaOH}-\mathrm{P}$, and thus are hostile to these extremophilic micro-organisms.

TAB LE 4 Colony-forming units (CFUs) on LB agar and plate count agar plates without amendments, amended with water only, and amended with $10 \%$ monosodium phosphate

\begin{tabular}{lllllll}
$\begin{array}{l}\text { Type of culture } \\
\text { plate }\end{array}$ & Amendment & MES & PONR-2 & Yungay & TZ-4 & $2.39 \times 10^{5}$ \\
\hline LB agar & None & 17 & 28 & 33 & $2.95 \times 10^{3}$ \\
& Water & 7 & $7.98 \times 10^{3}$ & $3.71 \times 10^{3}$ & $1.23 \times 10^{6}$ & $1.17 \times 10^{3}$ \\
& Phosphate & 0 & 0 & 904 & $4.92 \times 10^{5}$ & $3.68 \times 10^{5}$ \\
\hline Plate count agar & None & 167 & 190 & $5.17 \times 10^{3}$ & $2.90 \times 10^{6}$ & $6.00 \times 10^{3}$ \\
& Water & $1.36 \times 10^{3}$ & $8.56 \times 10^{4}$ & $6.96 \times 10^{4}$ & $1.33 \times 10^{7}$ & $1.25 \times 10^{5}$ \\
& Phosphate & 58 & 75 & $4.84 \times 10^{3}$ & $6.38 \times 10^{6}$ & $5.80 \times 10^{6}$ \\
\hline
\end{tabular}


TAB LE 5 The relative microbial growth rate on agar plates with excessive phosphate amendments, illustrating the change in order of magnitude of CFUs with phosphate amendments (all variables are scaled by logarithmic transformation relative to water only amendments). Bold values are those with the absolute change value in the order of magnitude greater than 1

\begin{tabular}{lll} 
Site & LB agar plates & $\begin{array}{l}\text { Plate count } \\
\text { agar plates }\end{array}$ \\
\hline MES & -0.86 & -1.37 \\
\hline PONR-2 & -3.90 & -3.06 \\
\hline Yungay & -0.61 & -1.16 \\
\hline TZ-4 & -0.40 & -0.32 \\
\hline TZ-5 & 2.50 & 1.67 \\
\hline
\end{tabular}

\section{2 | Phosphoenzymes and phosphate pathways}

Several phosphoenzymes can drive exchange reactions between the stable oxygen isotopes of phosphate and surrounding water. The most studied phosphoenzymes are inorganic pyrophosphatase, alkaline and acid phosphatases, DNase, RNase, 5'-nucleotidase, and phytases, which are all found to be primary phosphoenzymes in Atacama microbiomes (Table 3). These enzymes are broadly involved in $\mathrm{P}$ compound degradation pathways.

Pathway prediction analyses show that the majority of phosphate pathways are biosynthesis of microbial $\mathrm{P}$, including pentose phosphate pathways, glycolysis, biosynthesis of sugar-nucleotides, purine and pyrimidine nucleotides, phospholipids, cell walls, vitamins, secondary phosphatic metabolites, and polysaccharides. A relatively small proportion of pathways (13 out of 74 ) were identified to be degradation pathways or hydrolysis of $\mathrm{P}$ compounds (Figure 7), which might be attributed to the dormancy of indigenous microbial communities that were only occasionally activated by moisture elevations (Schulze-Makuch et al., 2018). The most abundant degradation pathways (6 of 13) participate in glycolysis and nucleotide degradation. The less abundant degradation pathways are subclasses of sugar degradation, phospholipid degradation, and methylphosphonate degradation (Figure 7).

Among these pathways, inorganic pyrophosphatase plays a role in methylphosphonate degradation and any hydrolysis of pyrophosphate into two phosphate molecules; it is also a highly conserved phosphoenzyme that ubiquitously exists across all organisms (Knowles, 1980) (Figure 1). DNase and RNase break the phosphodiester bonds of corresponding nucleic acids, and alkaline phosphatase is responsible in completing DNA and RNA degradation by hydrolyzing nucleotides into nucleosides and single phosphate molecules (Liang \& Blake, 2006, 2009) (Figure 1). Alkaline phosphatase is also involved in glycolysis II (from fructose 6-phosphate) (Cho, Seo, Kim, Jung, \& Park, 2012). Pathways associated with 5'-nucleotidase and acid phosphatase are found to be involved in nucleotide degradation (Passariello et al., 2006). Pathways of phytases, such as phytate degradation I, were not identified in our sequence data, and the abundance of phytases is significantly lower than other phosphoenzymes. These data suggest that phytases are not the dominant drivers of stable oxygen isotope exchange between soil phosphate and the surrounding water.

\section{3 | Phosphate $\delta^{18} \mathrm{O}$}

The dominant pool of $\mathrm{P}$ was $\mathrm{Ca}$-bound $(\mathrm{HCl}$-extractable) phosphate at all of the sites sampled (Figure 4). This pool either represents (a) the primary mineral $\mathrm{P}$ preserved in bedrock, or (b) $\mathrm{P}$ formed during early diagenesis as a result of the high $\mathrm{pH}$ of the soils, which promotes conversion of resin-P to Ca-P minerals (Oburger et al., 2011; Urrutia et al., 2014). To identify any biosignatures in soil $\delta^{18} \mathrm{O}_{\mathrm{PO} 4}$, it is important to first differentiate the stable oxygen isotope fingerprints of biogenic phosphoenzyme-driven water-phosphate equilibration from lithogenic P (Blake et al., 2005; Gross \& Angert, 2015) (Figure 1).

The primary bedrock of our sampling sites is generally composed of mixed mafic igneous and sedimentary rocks (Figure $5 \mathrm{~d}$ ): Our five study sites are all largely characterized by Mesozoic-Cenozoic sedimentary rocks and igneous rocks ranging in age from the Paleozoic to Cenozoic eras (Farmer, 2003) (Figure 2). As the bedrock compositions remain relatively constant throughout the hyperarid to arid profile, the primary $\mathrm{Ca}-\mathrm{P}$ endmember should be stable throughout the sites and should reliably reflect the bedrock $\delta^{18} \mathrm{O}_{\mathrm{PO} 4}$.

$\delta^{18} \mathrm{O}_{\mathrm{PO} 4}$ under magmatic conditions is dominantly constrained by equilibrium isotope exchange at high temperature, while $\delta^{18} \mathrm{O}_{\mathrm{PO} 4}$ of clastic sedimentary rocks is much more variable and can reflect decreasing ocean temperatures since the Cretaceous (Shemesh, Kolodny, \& Luz, 1988). Normally, igneous rocks contain lower $\delta^{18} \mathrm{O}_{\mathrm{PO} 4}$ values than sedimentary rocks, with igneous $\delta^{18} \mathrm{O}_{\mathrm{PO} 4}$ varying between 4 and 11\%o (Angert et al., 2012; Blake et al., 2010; Jaisi \& Blake, 2010; Markel, Kolodny, Luz, \& Nishri, 1994; Mizota, Domon, $\&$ Yoshida, 1992). $\delta^{18} \mathrm{O}_{\mathrm{PO} 4}$ of sedimentary rocks drops significantly from modern $(23 \%$ ) to Late Cretaceous (19\%o), with the lowest value (12.8\%) recorded from the Permian. These trends suggest that ocean temperatures were higher at about $100 \mathrm{Myr}$ ago, and post-depositional ${ }^{18} \mathrm{O}$ exchange took place between phosphate and the ambient water, as mainly directed by the activity of phosphoenzymes, usually inorganic pyrophosphatase (Shemesh, Kolodny, \& Luz, 1983; Shemesh et al., 1988; Tamburini et al., 2014). Accordingly, the $\delta^{18} \mathrm{O}_{\mathrm{PO} 4}$ values are always greater in post-Cretaceous sedimentary rocks than in igneous rocks, and can be further enriched by biological activity (Figure 1).

The most hyperarid sites we sampled (with precipitation $<2 \mathrm{~mm} /$ year; MES, PONR-2, and Yungay) all have low $\delta^{18} \mathrm{O}_{\mathrm{PO} 4}$ values in the Ca-P $(7.9,13.6$, and $11.2 \%$, respectively). Due to the minimal extent of microbial and other biological activity at these sites, this range in isotope values is taken to reflect a bedrock endmember $\delta^{18} \mathrm{O}_{\mathrm{PO} 4}$ signature for the wider region. Within the hyperarid core of the Atacama Desert, all three sites have similar proportions of magnesium $(1.1 \pm 0.1 \%)$ and iron (3.4 $\pm 0.4 \%)$ (Table 2$)$, and hence a similar source contribution from igneous rocks. The sedimentary rock source to MES soils is derived from both Jurassic and Quaternary 
periods, which is partially older than the solely Quaternary sedimentary rock source to the PONR-2 and Yungay sites. As a result, the $\delta^{18} \mathrm{O}_{\mathrm{PO} 4}$ value of MES soils is the smallest (Table 2). This parent bedrock isotopic endmember is thought to have remained stable for millennia due to the hyperarid nature of the environment and the minimal isotope fractionation associated with abiotic cycling of $P$ (Figure 1) (Azua-Bustos et al., 2015).

Arid sites (TZ-4 and TZ-5), on the other hand, have a higher abundance of magnesium and iron contents than hyperarid sites (Table 2 and Figure $5 \mathrm{~d}$ ), indicating a larger proportion of igneous source rocks. However, the $\delta^{18} \mathrm{O}_{\mathrm{PO} 4}$ of $\mathrm{Ca}-\mathrm{P}$ plateaus at higher values $(22.6 \pm 0.7 \%$ o $)$ at these two more humid sites. This distinct shift in $\delta^{18} \mathrm{O}_{\mathrm{PO} 4}$ coincides with high TOC, TON, and microbial P (Figure 6bd), indicating a major change in the source of Ca-P for sites with rainfall in excess of $15 \mathrm{~mm}$ /year. This trend suggests that the primary mineral $\delta^{18} \mathrm{O}_{\mathrm{PO} 4}$ signature has been overwritten, controlled by microbial phosphoenzyme hydrolysis and incorporating the $\delta^{18} \mathrm{O}$ signature of water.

Only hydrolysis by inorganic pyrophosphatase results in a positive $\delta^{18} \mathrm{O}_{\mathrm{PO} 4}$ (Figure 1). The results of enzyme and pathway prediction analyses imply that the hydrolysis by inorganic pyrophosphatase is the most likely reaction to cycle $P$ in these environments, or that this process will rapidly overprint other $\mathrm{P}$ utilization strategies, in agreement with previous studies (Blake, 1998; Blake et al., 2005; Gross \& Angert, 2015; Jaisi, Kukkadapu, Stout, Varga, \& Blake, 2011; Tamburini et al., 2014).

In our sampling regions of the Atacama Desert, available moisture for inorganic pyrophosphatase hydrolysis is minimal. Some possible water sources for life might be sporadic rainfall and infrequent inland fog. For example, previous studies found that biological activity increases in Atacama soils after infrequent rainfall events (Schulze-Makuch et al., 2018; Vidiella et al., 1999) and that Atacama microbial communities and shrubs are capable of utilizing atmospheric water sources (Azua-Bustos et al., 2011; Mooney, Gulmon, Ehleringer, \& Rundel, 1980; Stomeo et al., 2013). Groundwater might also act as a minor source of water for life. Importantly, hydration water of hydrated minerals such as the large gypsum reservoir in the Atacama Desert (Dong, Rech, Jiang, Sun, \& Buck, 2007; Farias et al., 2014; Rech, Quade, \& Hart, 2003) is potentially the main water source of endolithic micro-organisms and plants during the dry period (Palacio et al., 2014).

The inorganic pyrophosphatase-driven biogenic $\delta^{18} \mathrm{O}_{\mathrm{PO} 4}$ signature can be calculated by Eq. (4) using source water $\delta^{18} \mathrm{O}_{\mathrm{H} 2 \mathrm{O}}$. Due to the long-term strong effects of evaporation, water sources in the Atacama Desert are heavier in $\delta^{18} \mathrm{O}$ than in most other settings on Earth (Cappa, Hendricks, DePaolo, \& Cohen, 2003; Dansgaard, 1964; Surma, Assonov, Herwartz, Voigt, \& Staubwasser, 2018). $\delta^{18} \mathrm{O}_{\mathrm{H} 2 \mathrm{O}}$ of rainwater generally increases as the altitude gets lower, such that between 2,200 and 3,000 $\mathrm{m}$ above sea level (a.s.l.), rainwater $\delta^{18} \mathrm{O}_{\mathrm{H} 2 \mathrm{O}}$ varies between -12 and $-2 \%$ (R Aravena, Peña, Grilli, Suzuki, \& Mordeckai, 1989; R. Aravena et al., 1999; Fritz, Suzuki, Silva, \& Salati, 1981). During March 2015, the $\delta^{18} \mathrm{O}_{\mathrm{H} 2 \mathrm{O}}$ of rainwater from an extreme precipitation event in the Atacama Desert varied between
-9 and $-1 \%$ at 100 to $2,500 \mathrm{~m}$ a.s.l. (Jordan et al., 2019), consistent with previous data at this altitude range (Boschetti, Cifuentes, lacumin, \& Selmo, 2019; Schotterer et al. 1996). At about 500 to $1,600 \mathrm{~m}$ a.s.I., altitudes spanning our sampling locations (Table 1 ), the $\delta^{18} \mathrm{O}_{\mathrm{H} 2 \mathrm{O}}$ value of rainwater is expected to be closer to $-2 \%$ o than $-10 \%$. In addition, local fog data for the Atacama Desert show that the $\delta^{18} \mathrm{O}_{\mathrm{H} 2 \mathrm{O}}$ of fog varies between -3 and $-1 \%$ o (R. Aravena, Suzuki, \& Pollastri, 1989; Strauch, Oyarzun, Fiebig-Wittmaack, Gonzalez, \& Weise, 2006). The range of Atacama groundwater $\delta^{18} \mathrm{O}_{\mathrm{H} 2 \mathrm{O}}$ is about -11 to $+3 \%$ (Alpers \& Whittemore, 1990; R. Aravena et al., 1989; Herrera et al., 2018; Scheihing, Moya, Struck, Lictevout, \& Troger, 2018), but groundwater is less likely to be a significant source to Atacama biological communities. Moreover, the $\delta^{18} \mathrm{O}_{\mathrm{H} 2 \mathrm{O}}$ of gypsum hydration water has a fractionation factor $\alpha^{18} \mathrm{O}_{\text {gypsum-water }}$ of $1.0035 \pm 0.0002$ with surrounding water sources (Gazquez, Evans, $\&$ Hodell, 2017), so the hydration water $\delta^{18} \mathrm{O}_{\mathrm{H} 2 \mathrm{O}}$ of Atacama gypsum is anticipated to be slightly higher than the other water oxygen isotope ratios discussed above.

The results of enzyme and pathway predictions imply that the hydrolysis by inorganic pyrophosphatase dominates the biogeochemical $P$ dynamics in Atacama soils (Figure 1). Therefore, if we assume that isotopic equilibrium has been reached the arid sites (TZ-4 and TZ-5), we can re-arrange the microbial P turnover equation by inorganic pyrophosphatase (Eq. (4)) to establish the primary moisture source for the biological communities surviving and actively cycling $\mathrm{P}$ in this environment. Using the average temperature recorded from the nearest meteorological stations (Table 1) and supposed $\delta^{18} \mathrm{O}_{\mathrm{PO} 4}$ equilibrium values for each site (Table 2 ), we calculate the theoretical $\delta^{18} \mathrm{O}_{\mathrm{H} 2 \mathrm{O}}$ of source water to be $-3.31 \pm 0.34 \%$ at TZ-4, $+2.04 \pm 0.16 \%$ at TZ-5, and $-1.04 \pm 0.17 \%$ o at the TZ-5 pit adjacent to shrubs. All values fall within the higher range expected for potential moisture sources, confirming the highly evaporative nature of the moisture available for biological communities (Hsieh, Chadwick, Kelly, \& Savin, 1998).

At site TZ-5, we see differences between theoretical $\delta^{18} \mathrm{O}_{\mathrm{H} 2 \mathrm{O}}$ from the two samples collected. Considering the relationship between source water $\delta^{18} \mathrm{O}_{\mathrm{H} 2 \mathrm{O}}$ and biogenic soil $\delta^{18} \mathrm{O}_{\mathrm{PO} 4}$ discussed above, some explanations for this heterogeneity might be that (a) the equilibrium of water-phosphate interaction mainly driven by soil microbial inorganic pyrophosphatase is not fully reached, and hence, the biological fingerprints in $\mathrm{Ca}-\mathrm{P} \delta^{18} \mathrm{O}_{\mathrm{PO} 4}$ only reflect a quasi-equilibrium state, (b) the most abundant DNases and RNases are fractionating $\delta^{18} \mathrm{O}_{\mathrm{PO} 4}$ during nucleic acid degradation (Table 3 and Figures 1 and 7), or (c) the water sources for life are distinct from each other even on a small spatial scale. Further investigation is required to ascertain the driving force behind these small differences in calculated source water $\delta^{18} \mathrm{O}$ values at site TZ-5.

However, observed differences of $\sim 5 \%$ o between the calculated isotopic signature of source water at TZ-4 and TZ-5 point to a stronger driving force. One clear difference between the sites is their altitudes, where TZ-5 is at almost 1,000 m lower elevation than TZ-4 (Table 1). When considering this difference, theoretical water isotope values follow the expected trend of decreasing rainwater 
$\delta^{18} \mathrm{O}_{\mathrm{H} 2 \mathrm{O}}$ with altitude (R. Aravena et al., 1999; Jordan et al., 2019). Again this finding requires further investigation, but if correct, this suggests that rainwater does indeed dominate water resources at these arid sites, even under hostile conditions of $<20 \mathrm{~mm} / \mathrm{yr}$ rainfall (Orlando et al., 2010; Schulze-Makuch et al., 2018). How exactly this rainwater is accessed by the biological community is still uncertain. It can be assumed that a proportion is available directly after a rain event but that there must also be a critical slow release water reservoir, or regular additional water (e.g., fog and groundwater), which reflects rainfall isotope values and is utilized between the infrequent rainfall events. We suggest that gypsum hydration water is the most likely reserve of bioavailable moisture between rainfall events in these environments (Palacio et al., 2014). The fractionation of $\delta^{18} \mathrm{O}$ during uptake into gypsum is minimal but slightly positive, potentially explaining the theoretical positive isotope value of $+2.04 \%$ at TZ-5 which is higher than all theoretical rainwater and fog sources outlined above. The uptake of water into the gypsum mineral phase should also preserve the altitude-driven difference between rainfall at TZ-4 and TZ- 5 as suggested by our theoretical $\delta^{18} \mathrm{O}_{\mathrm{H} 2 \mathrm{O}}$ calculations.

On current Mars, diurnal cycles promote the formation of a thin layer of liquid water within the subsurface (Altheide, Chevrier, Nicholson, \& Denson, 2009; Chevrier, Hanley, \& Altheide, 2009; Cull et al., 2010; Kereszturi \& Rivera-Valentin, 2012; Martinez \& Renno, 2013; Meslin et al., 2013). This process means that small volumes of water are available to nourish indigenous Martian "microbes," possibly allowing them to slowly thrive and cycle key nutrients (Stevenson et al., 2015). Additionally, during portions of its planetary history Mars was far wetter than today (Craddock \& Howard, 2002). On an earlier, wetter Mars, moisture might have in principle supported significant biologically catalyzed oxygen atom exchange and departures from the igneous $\delta^{18} \mathrm{O}$ baseline (Figure 1). The arid sites characterized by biogenic $\delta^{18} \mathrm{O}_{\mathrm{PO} 4}$ signature in this study have experienced similar climatic conditions to the middle-late Hesperian Mars, 3 billion years ago (Coleman, Dinwiddie, \& Casteel, 2007; Oberlin, Claire, \& Kounaves, 2018). We can refer to the global databases of Martian valley networks (Hynek, Beach, \& Hoke, 2010) to locate feasible ancient water bodies such as outflow channels, ocean basins, deltaic deposits, and fan-shaped aprons (Clifford \& Parker, 2001; Di Achille \& Hynek, 2010; Di Achille, Ori, \& Reiss, 2007; Irwin, Maxwell, Howard, Craddock, \& Leverington, 2002; Malin \& Edgett, 2003). Thus, we suggest that the $\delta^{18} \mathrm{O}_{\mathrm{PO} 4}$-based detectable Martian life signs could concentrate at these "water body" landscapes in areas of temperate temperature, for example, around the equatorial regions.

\section{5 | CONCLUSIONS}

Here, we demonstrate the utility of the $\delta^{18} \mathrm{O}_{\mathrm{PO} 4}$ proxy in detecting biological phosphorus cycling in a Mars-analogue system. In the Atacama Desert, at hyperarid sites with annual rainfall $<2 \mathrm{~mm}$, low $\delta^{18} \mathrm{O}_{\mathrm{PO} 4}$ values reflect the primarily magmatic bedrock source, indicating a significant lack of biological activity. However, at arid sites where annual precipitation $>10 \mathrm{~mm}$ and microbial cycling plays a key role, the $\delta^{18} \mathrm{O}_{\mathrm{PO} 4}$ values move away from this lithogenic endmember. These results suggest that as biological activity increases, the $\delta^{18} \mathrm{O}_{\mathrm{PO} 4}$ of mineral $\mathrm{P}$ gradually shifts toward values closer to the equilibrium function of $\delta^{18} \mathrm{O}_{\mathrm{H} 2 \mathrm{O}}$, providing a crucial biosignature if the $\delta^{18} \mathrm{O}_{\mathrm{H} 2 \mathrm{O}}$ can be approximated. Critically, we have shown that microbial activity is capable of replacing authigenic $P$ with biogenic $P$ over millions of years, even under relatively inhospitable conditions similar to the middle-late Hesperian Mars. These $\delta^{18} \mathrm{O}_{\mathrm{PO} 4}$ values further suggest that microbial ecosystems living in such extreme environments can presumably utilize water from a variety of sources in addition to rainfall, including hydrated minerals.

\section{ACKNOWLEDGMENTS}

We thank Adam Wyness from Scottish Oceans Institute, School of Biology, University of St Andrews, St Andrews KY16 8LB, UK, and Department of Zoology and Entomology, Rhodes University, Grahamstown 6139, South Africa, for assisting the soil DNA extractions.

\section{CONFLICT OF INTEREST}

We have no conflict of interest to declare.

\section{AUTHOR CONTRIBUTION}

J.S., A.Z., and M.C. sampled the study sites. J.S. performed soil characterization, DNA extraction, cell culture, and all statistical analyses. J.S. and A.S. performed sequential phosphate extraction. A.S. performed stable oxygen isotope measurements in phosphate. All authors wrote and approved the final manuscript. Jianxun Shen investigated the study, designed methodology, provided software, cured and visualized data, and wrote the original draft. Mark Claire acquired funding, supervised the study, and reviewed and edited the manuscript. Andrew Smith designed methodology, performed validation, and reviewed and edited the manuscript. Aubrey Zerkle administered the project, supervised the study, and reviewed and edited the manuscript.

\section{DATA AVAILABILITY STATEMENT}

Sequencing data for enzyme and pathway analyses in this study can be found in the National Center for Biotechnology Information (NCBI) under the Sequence Read Archive (SRA) accession numbers of SRX7370993, SRX7370998, and SRX7370989.

\section{ORCID}

Jianxun Shen (iD https://orcid.org/0000-0002-3942-1692

Aubrey L. Zerkle iD https://orcid.org/0000-0003-2324-1619

\section{REFERENCES}

Adcock, C. T., Hausrath, E. M., \& Forster, P. M. (2013). Readily available phosphate from minerals in early aqueous environments on Mars. Nature Geoscience, 6(10), 824-827. https://doi.org/10.1038/ Ngeo1923. 
Alpers, C. N., \& Whittemore, D. O. (1990). Hydrogeochemistry and Stable Isotopes of Ground and Surface Waters from 2 Adjacent Closed Basins, Atacama Desert. Northern Chile. Applied Geochemistry, 5(5-6), 719-734. https://doi.org/10.1016/0883-2927(90)90067-F.

Altheide, T., Chevrier, V., Nicholson, C., \& Denson, J. (2009). Experimental investigation of the stability and evaporation of sulfate and chloride brines on Mars. Earth and Planetary Science Letters, 282(1-4), 69-78. https://doi.org/10.1016/j.epsl.2009.03.002.

Ameen, F., AlYahya, S. A., AlNadhari, S., Alasmari, H., Alhoshani, F., \& Wainwright, M. (2019). Phosphate solubilizing bacteria and fungi in desert soils: species, limitations and mechanisms. Archives of Agronomy and Soil Science, 65(10), 1446-1459. https://doi. org/10.1080/03650340.2019.1566713.

Amelung, W., Blume, H.-P., Fleige, H., Horn, R., Kandeler, E., KögelKnabner, I., ... Wilke, B.-M. (2018). Scheffer/Schachtschabel Lehrbuch der Bodenkunde. Heidelberg, Berlin: Springer-Verlag.

Angert, A., Weiner, T., Mazeh, S., \& Sternberg, M. (2012). Soil Phosphate Stable Oxygen Isotopes across Rainfall and Bedrock Gradients. Environmental Science \& Technology, 46(4), 2156-2162. https://doi. org/10.1021/es203551s.

Aravena, R., Peña, H., Grilli, A., Suzuki, O., \& Mordeckai, M. (1989). Evolución isotópica de las lluvias y origen de las masas de aire en el Altiplano chileno (pp. 129-142). Vienna: Isotope Hydrology Investigations in Latin America. IAEA.

Aravena, R., Suzuki, O., Pena, H., Pollastri, A., Fuenzalida, H., \& Grilli, A. (1999). Isotopic composition and origin of the precipitation in Northern Chile. Applied Geochemistry, 14(4), 411-422. https://doi. org/10.1016/S0883-2927(98)00067-5.

Aravena, R., Suzuki, O., \& Pollastri, A. (1989). Coastal Fog and Its Relation to Groundwater in the Iv-Region of Northern Chile. Chemical Geology, 79(1), 83-91. https://doi.org/10.1016/01689622(89)90008-0.

Azua-Bustos, A., Caro-Lara, L., \& Vicuna, R. (2015). Discovery and microbial content of the driest site of the hyperarid Atacama Desert. Chile. Environmental Microbiology Reports, 7(3), 388-394. https://doi. org/10.1111/1758-2229.12261.

Azua-Bustos, A., Fairen, A. G., Gonzalez-Silva, C., Ascaso, C., Carrizo, D., Fernandez-Martinez, M. A., ... Parro, V. (2018). Unprecedented rains decimate surface microbial communities in the hyperarid core of the Atacama Desert. Scientific Reports, 8, 16706. https://doi. org/10.1038/s41598-018-35051-w.

Azua-Bustos, A., Gonzalez-Silva, C., Mancilla, R. A., Salas, L., GomezSilva, B., McKay, C. P., \& Vicuna, R. (2011). Hypolithic Cyanobacteria Supported Mainly by Fog in the Coastal Range of the Atacama Desert. Microbial Ecology, 61(3), 568-581. https://doi.org/10.1007/ s00248-010-9784-5.

Bagaley, D. R. (2006). Uncovering bacterial diversity on and below the surface of a hyper-arid environment, the Atacama Desert, Chile. (Master of Science), Louisiana State University and Agricultural and Mechanical College.

Barbera, P., Kozlov, A. M., Czech, L., Morel, B., Darriba, D., Flouri, T., \& Stamatakis, A. (2019). EPA-ng: Massively Parallel Evolutionary Placement of Genetic Sequences. Systematic Biology, 68(2), 365-369. https://doi.org/10.1093/sysbio/syy054.

Barker, D. S. (1978). Magmatic Trends on Alkali-Iron-Magnesium Diagrams. American Mineralogist, 63(5-6), 531-534.

Blake, R. E. (1998). Enzyme-catalyzed oxygen isotope exchange between inorganic phosphate and water: Reaction rates and temperature dependence at $5.7-30^{\circ} \mathrm{C}$. Mineralogical Magazine, 62, 163-164.

Blake, R. E., Alt, J. C., \& Martini, A. M. (2001). Oxygen isotope ratios of PO4: An inorganic indicator of enzymatic activity and P metabolism and a new biomarker in the search for life. Proceedings of the National Academy of Sciences of the United States of America, 98(5), 2148-2153. https://doi.org/10.1073/pnas.051515898.
Blake, R. E., Chang, S. J., \& Lepland, A. (2010). Phosphate oxygen isotopic evidence for a temperate and biologically active Archaean ocean. Nature, 464(7291), 113-145. https://doi.org/10.1038/natur e08952.

Blake, R. E., O'Neil, J. R., \& Surkov, A. V. (2005). Biogeochemical cycling of phosphorus: Insights from oxygen isotope effects of phosphoenzymes. American Journal of Science, 305(6-8), 596-620. https://doi. org/10.2475/ajs.305.6-8.596.

Bolyen, E., Rideout, J. R., Dillon, M. R., Bokulich, N. A., Abnet, C. C., AlGhalith, G. A., ... Caporaso, J. G. (2019). Reproducible, interactive, scalable and extensible microbiome data science using QIIME 2. Nature Biotechnology, 37(8), 852-857. https://doi.org/10.1038/s4158 7-019-0209-9.

Boschetti, T., Cifuentes, J., lacumin, P., \& Selmo, E. (2019). Local Meteoric Water Line of Northern Chile (18 degrees S-30 degrees S): An Application of Error-in-Variables Regression to the Oxygen and Hydrogen Stable Isotope Ratio of Precipitation. Water, 11(4), 791. https://doi.org/10.3390/w11040791.

Broadhurst, F. M., \& Loring, D. H. (1970). Rates of Sedimentation in Upper Carboniferous of Britain. Lethaia, 3(1), 1. https://doi. org/10.1111/j.1502-3931.1970.tb01260.x.

Callahan, B. J., McMurdie, P. J., Rosen, M. J., Han, A. W., Johnson, A. J. A., \& Holmes, S. P. (2016). DADA2: High-resolution sample inference from Illumina amplicon data. Nature Methods, 13(7), 581. https://doi. org/10.1038/Nmeth.3869.

Cappa, C. D., Hendricks, M. B., DePaolo, D. J., \& Cohen, R. C. (2003). Isotopic fractionation of water during evaporation. Journal of Geophysical Research-Atmospheres, 108(D16), 4525. https://doi. org/10.1029/2003jd003597.

Caspi, R., Billington, R., Ferrer, L., Foerster, H., Fulcher, C. A., Keseler, I. M., ... Karp, P. D. (2016). The MetaCyc database of metabolic pathways and enzymes and the BioCyc collection of pathway/genome databases. Nucleic Acids Research, 44(D1), D471-480. https://doi. org/10.1093/nar/gkv1164.

Caspi, R., Billington, R., Fulcher, C. A., Keseler, I. M., Kothari, A., Krummenacker, M., ... Karp, P. D. (2018). The MetaCyc database of metabolic pathways and enzymes. Nucleic Acids Research, 46(D1), D633-D639. https://doi.org/10.1093/nar/gkx935.

Chang, S. J., \& Blake, R. E. (2015). Precise calibration of equilibrium oxygen isotope fractionations between dissolved phosphate and water from 3 to 37 degrees C. Geochimica Et Cosmochimica Acta, 150, 314329. https://doi.org/10.1016/j.gca.2014.10.030.

Chevrier, V., Hanley, J., \& Altheide, T. (2009). Stability of perchlorate hydrates and their liquid solutions at the Phoenix landing site, Mars (vol 36, art no L10202, 2009). Geophysical Research Letters, 36, 14. https://doi.org/10.1029/2009gl040523.

Chislock, M. F., Doster, E., Zitomer, R. A., \& Wilson, A. (2013). Eutrophication: causes, consequences, and controls in aquatic ecosystems. Nature Education Knowledge, 4(4), 10.

Cho, H. S., Seo, S. W., Kim, Y. M., Jung, G. Y., \& Park, J. M. (2012). Engineering glyceraldehyde-3-phosphate dehydrogenase for switching control of glycolysis in Escherichia coli. Biotechnology and Bioengineering, 109(10), 2612-2619. https://doi.org/10.1002/ bit. 24532 .

Cleveland, C. C., \& Liptzin, D. (2007). C : N : P stoichiometry in soil: is there a "Redfield ratio" for the microbial biomass? Biogeochemistry, 85(3), 235-252. https://doi.org/10.1007/s10533-007-9132-0.

Clifford, S. M., \& Parker, T. J. (2001). The evolution of the Martian hydrosphere: Implications for the fate of a primordial ocean and the current state of the northern plains. Icarus, 154(1), 40-79. https:// doi.org/10.1006/icar.2001.6671

Coleman, N. M., Dinwiddie, C. L., \& Casteel, K. (2007). High outflow channels on Mars indicate Hesperian recharge at low latitudes and the presence of Canyon Lakes. Icarus, 189(2), 344-361. https://doi. org/10.1016/j.icarus.2007.01.020. 
Cordero, R. R., Damiani, A., Jorquera, J., Sepulveda, E., Caballero, M., Fernandez, S., ... Labbe, F. (2018). Ultraviolet radiation in the Atacama Desert. Antonie Van Leeuwenhoek, 111(8), 1301-1313. https://doi. org/10.1007/s10482-018-1075-z.

Craddock, R. A., \& Howard, A. D. (2002). The case for rainfall on a warm, wet early Mars. Journal of Geophysical Research-Planets, 107(E11), 1505. https://doi.org/10.1029/2001je001505.

Crain, G. M., McLaren, J. R., Brunner, B., \& Darrouzet-Nardi, A. (2018). Biologically Available Phosphorus in Biocrust-Dominated Soils of the Chihuahuan Desert. Soil Systems, 2(4), 56. https://doi.org/10.3390/ soilsystems2040056.

Crits-Christoph, A., Robinson, C. K., Barnum, T., Fricke, W. F., Davila, A. F., Jedynak, B., ... DiRuggiero, J. (2013). Colonization patterns of soil microbial communities in the Atacama Desert. Microbiome, 1, 28. https://doi.org/10.1186/2049-2618-1-28.

Cull, S. C., Arvidson, R. E., Catalano, J. G., Ming, D. W., Morris, R. V., Mellon, M. T., \& Lemmon, M. (2010). Concentrated perchlorate at the Mars Phoenix landing site: Evidence for thin film liquid water on Mars. Geophysical Research Letters, 37, 22. https://doi.org/10.1029/2010g 1045269.

Czech, L., \& Stamatakis, A. (2019). Scalable methods for analyzing and visualizing phylogenetic placement of metagenomic samples. Plos One, 14(5), e0217050. https://doi.org/10.1371/journal.pone.0217050.

Dahms, A. S., \& Boyer, P. D. (1973). Occurrence and Characteristics of 0-18 Exchange-Reactions Catalyzed by Sodium-Dependent and Potassium-Dependent Adenosine Triphosphatases. Journal of Biological Chemistry, 248(9), 3155-3162.

Dansgaard, W. (1964). Stable Isotopes in Precipitation. Tellus, 16(4), 436-468.

Di Achille, G., \& Hynek, B. M. (2010). Ancient ocean on Mars supported by global distribution of deltas and valleys. Nature Geoscience, 3(7), 459-463. https://doi.org/10.1038/Ngeo891.

Di Achille, G., Ori, G. G., \& Reiss, D. (2007). Evidence for late Hesperian lacustrine activity in Shalbatana Vallis, Mars. Journal of Geophysical Research-Planets, 112(E7), e002858. https://doi.org/10.1029/2006j e002858.

Dong, H. L., Rech, J. A., Jiang, H. C., Sun, H., \& Buck, B. J. (2007). Endolithic cyanobacteria in soil gypsum: Occurrences in Atacama (Chile), Mojave (United States), and Al-Jafr Basin (Jordan) deserts. Journal of Geophysical Research-Biogeosciences, 112(G2), G02030. https://doi.org/10.1029/2006jg000385.

Douglas, G. M., Maffei, V. J., Zaneveld, J., Yurgel, S. N., Brown, J. R., Taylor, C. M., ...Langille, M. G. (2019). PICRUSt2: An improved and extensible approach for metagenome inference. BioRxiv, 672295.

Dunai, T. J., Lopez, G. A. G., \& Juez-Larre, J. (2005). Oligocene-Miocene age of aridity in the Atacama Desert revealed by exposure dating of erosion-sensitive landforms. Geology, 33(4), 321-324. https://doi. org/10.1130/G21184.1.

Eddy, S., \& Wheeler, T. (2007). HMMER-biosequence analysis using profile hidden Markov models. Retrieved from http://hmmer.janelia.org.

Edgar, R. C., Haas, B. J., Clemente, J. C., Quince, C., \& Knight, R. (2011). UCHIME improves sensitivity and speed of chimera detection. Bioinformatics, 27(16), 2194-2200. https://doi.org/10.1093/bioin formatics/btr381.

Ewing, S. A., Michalski, G., Thiemens, M., Quinn, R. C., Macalady, J. L., Kohl, S., ... Amundson, R. (2007). Rainfall limit of the N cycle on Earth. Global Biogeochemical Cycles, 21, 3. https://doi.org/10.1029/2006g b002838.

Fabre, A., Gauquelin, T., Vilasante, F., Ortega, A., \& Puig, H. (2006). Phosphorus content in five representative landscape units of the Lomas de Arequipa (Atacama Desert-Peru). Catena, 65(1), 80-86. https://doi.org/10.1016/j.catena.2005.10.004.

Farias, M. E., Contreras, M., Rasuk, M. C., Kurth, D., Flores, M. R., Poire, D. G., ... Visscher, P. T. (2014). Characterization of bacterial diversity associated with microbial mats, gypsum evaporites and carbonate microbialites in thalassic wetlands: Tebenquiche and La Brava, Salar de Atacama, Chile. Extremophiles, 18(2), 311-329. https://doi. org/10.1007/s00792-013-0617-6.

Farmer, G. (2003). Continental basaltic rocks. Treatise on Geochemistry, 3,659 .

Fritz, P., Suzuki, O., Silva, C., \& Salati, E. (1981). Isotope Hydrology of Groundwaters in the Pampa Del Tamarugal. Chile. Journal of Hydrology, 53(1-2), 161-184. https://doi.org/10.1016/0022-1694(81)90043-3.

Garreaud, R. D., Molina, A., \& Farias, M. (2010). Andean uplift, ocean cooling and Atacama hyperaridity: A climate modeling perspective. Earth and Planetary Science Letters, 292(1-2), 39-50. https://doi. org/10.1016/j.epsl.2010.01.017.

Garreaud, R. D., Vuille, M., Compagnucci, R., \& Marengo, J. (2009). Present-day South American climate. Palaeogeography Palaeoclimatology Palaeoecology, 281(3-4), 180-195. https://doi. org/10.1016/j.palaeo.2007.10.032.

Gazquez, F., Evans, N. P., \& Hodell, D. A. (2017). Precise and accurate isotope fractionation factors (alpha $0-17$, alpha $0-18$ and alpha D) for water and $\mathrm{CaSO} 4$ center dot $2 \mathrm{H}(2) \mathrm{O}$ (gypsum). Geochimica Et Cosmochimica Acta, 198, 259-270. https://doi.org/10.1016/j. gca.2016.11.001.

George, T. S., Giles, C. D., Menezes-Blackburn, D., Condron, L. M., GamaRodrigues, A. C., Jaisi, D., ... Haygarth, P. M. (2018). Organic phosphorus in the terrestrial environment: a perspective on the state of the art and future priorities (vol 427, pg 191, 2018). Plant and Soil, 427(1-2), 209-211. https://doi.org/10.1007/s11104-017-3488-2.

Golterman, H. L. (1973). Natural Phosphate Sources in Relation to Phosphate Budgets - Contribution to Understanding of Eutrophication. Water Research, 7(1-2), 3-17. https://doi. org/10.1016/0043-1354(73)90149-8.

Granger, S. J., Yang, Y. G., Pfahler, V., Hodgson, C., Smith, A. C., Le Cocq, K., ... Howden, N. J. K. (2018). The stable oxygen isotope ratio of resin extractable phosphate derived from fresh cattle faeces. Rapid Communications in Mass Spectrometry, 32(9), 703-710. https://doi. org/10.1002/rcm.8092.

Gross, A., \& Angert, A. (2015). What processes control the oxygen isotopes of soil bio-available phosphate? Geochimica Et Cosmochimica Acta, 159, 100-111. https://doi.org/10.1016/j.gca.2015.03.023.

Gross, A., Turner, B. L., Wright, S. J., Tanner, E. V. J., Reichstein, M., Weiner, T., \& Angert, A. (2015). Oxygen isotope ratios of plant available phosphate in lowland tropical forest soils. Soil Biology \& Biochemistry, 88, 354-361. https://doi.org/10.1016/j.soilbio.2015.06.015.

Guidry, M. W., \& Mackenzie, F. T. (2003). Experimental study of igneous and sedimentary apatite dissolution: control of $\mathrm{pH}$, distance from equilibrium, and temperature on dissolution rates. Geochimica Et Cosmochimica Acta, 67(16), 2949-2963. https://doi.org/10.1016/ S0016-7037(03)00265-5.

Gyaneshwar, P., Kumar, G. N., \& Parekh, L. J. (1998). Effect of buffering on the phosphate-solubilizing ability of microorganisms. World Journal of Microbiology \& Biotechnology, 14(5), 669-673. https://doi. org/10.1023/A:1008852718733.

Hartley, A. J., Chong, G., Houston, J., \& Mather, A. E. (2005). 150 million years of climatic stability: evidence from the Atacama Desert, northern Chile. Journal of the Geological Society, 162, 421-424. https://doi. org/10.1144/0016-764904-071.

Hecht, M. H., Kounaves, S. P., Quinn, R. C., West, S. J., Young, S. M. M., Ming, D. W., ... Smith, P. H. (2009). Detection of Perchlorate and the Soluble Chemistry of Martian Soil at the Phoenix Lander Site. Science, 325(5936), 64-67. https://doi.org/10.1126/scien ce.1172466.

Hedley, M. J., Stewart, J. W. B., \& Chauhan, B. S. (1982). Changes in inorganic and organic soil phosphorus fractions induced by cultivation practices and by laboratory incubations. Soil Science Society of America Journal, 46(5), 970-976. https://doi.org/10.2136/sssaj 1982.03615995004600050017x. 
Helfenstein, J., Pistocchi, C., Oberson, A., Tamburini, F., Goll, D. S., \& Frossard, E. (2020). Estimates of mean residence times of phosphorus in commonly considered inorganic soil phosphorus pools. Biogeosciences, 17(2), 441-454. https://doi.org/10.3929/ ethz-b-000399324.

Helfenstein, J., Tamburini, F., von Sperber, C., Massey, M. S., Pistocchi, C., Chadwick, O. A., ... Frossard, E. (2018). Combining spectroscopic and isotopic techniques gives a dynamic view of phosphorus cycling in soil. Nature Communications, 9, 3226. https://doi.org/10.1038/s4146 7-018-05731-2.

Herlemann, D. P. R., Labrenz, M., Jurgens, K., Bertilsson, S., Waniek, J. J., \& Andersson, A. F. (2011). Transitions in bacterial communities along the $2000 \mathrm{~km}$ salinity gradient of the Baltic Sea. Isme Journal, 5(10), 1571-1579. https://doi.org/10.1038/ismej.2011.41.

Herrera, C., Gamboa, C., Custodio, E., Jordan, T., Godfrey, L., Jodar, J., ... Saez, A. (2018). Groundwater origin and recharge in the hyperarid Cordillera de la Costa, Atacama Desert, northern Chile. Science of the Total Environment, 624, 114-132. https://doi.org/10.1016/j.scito tenv.2017.12.134.

Houston, J. (2006). Variability of precipitation in the Atacama desert: Its causes and hydrological impact. International Journal of Climatology, 26(15), 2181-2198. https://doi.org/10.1002/joc.1359.

Houston, J., \& Hartley, A. J. (2003). The central andean west-slope rainshadow and its potential contribution to the origin of HYPERARIDITY in the Atacama desert. International Journal of Climatology, 23(12), 1453-1464. https://doi.org/10.1002/joc.938.

Hsieh, J. C. C., Chadwick, O. A., Kelly, E. F., \& Savin, S. M. (1998). Oxygen isotopic composition of soil water: quantifying evaporation and transpiration. Geoderma, 82(1-3), 269-293. https://doi.org/10.1016/ S0016-7061(97)00105-5.

Huang, J. Y., Wang, P., Niu, Y. B., Yu, H. L., Ma, F., Xiao, G. J., \& Xu, X. (2018). Changes in C:N: P stoichiometry modify $N$ and $P$ conservation strategies of a desert steppe species Glycyrrhiza uralensis. Scientific Reports, 8, 12668. https://doi.org/10.1038/s41598-01830324-w.

Hynek, B. M., Beach, M., \& Hoke, M. R. T. (2010). Updated global map of Martian valley networks and implications for climate and hydrologic processes. Journal of Geophysical Research, 115, E09008. https://doi. org/10.1029/2009JE003548.

Illmer, P., \& Schinner, F. (1992). Solubilization of Inorganic Phosphates by Microorganisms Isolated from Forest Soils. Soil Biology \& Biochemistry, 24(4), 389-395. https://doi.org/10.1016/0038-0717(92)90199-8.

Irwin, R. P., Maxwell, T. A., Howard, A. D., Craddock, R. A., \& Leverington, D. W. (2002). A large paleolake basin at the head of Ma'adim Vallis, Mars. Science, 296(5576), 2209-2212. https://doi.org/10.1126/scien ce.1071143.

Jaisi, D. P., \& Blake, R. E. (2010). Tracing sources and cycling of phosphorus in Peru Margin sediments using oxygen isotopes in authigenic and detrital phosphates. Geochimica Et Cosmochimica Acta, 74(11), 3199-3212. https://doi.org/10.1016/j.gca.2010.02.030.

Jaisi, D. P., \& Blake, R. E. (2014). Advances in using oxygen isotope ratios of phosphate to understand phosphorus cycling in the environment. Advances in Agronomy, 125, 1-53.

Jaisi, D. P., Blake, R. E., \& Kukkadapu, R. K. (2010). Fractionation of oxygen isotopes in phosphate during its interactions with iron oxides. Geochimica Et Cosmochimica Acta, 74(4), 1309-1319. https://doi. org/10.1016/j.gca.2009.11.010.

Jaisi, D. P., Kukkadapu, R. K., Stout, L. M., Varga, T., \& Blake, R. E. (2011). Biotic and Abiotic Pathways of Phosphorus Cycling in Minerals and Sediments: Insights from Oxygen Isotope Ratios in Phosphate. Environmental Science \& Technology, 45(15), 6254-6261. https://doi. org/10.1021/es200456e.

Johnson, L. S., Eddy, S. R., \& Portugaly, E. (2010). Hidden Markov model speed heuristic and iterative HMM search procedure. Bmc Bioinformatics, 11, 431. https://doi.org/10.1186/1471-2105-11-431.
Jordan, T. E., Herrera, C., Godfrey, L. V., Colucci, S. J., Gamboa, C., Urrutia, J., ... Paul, J. F. (2019). Isotopic characteristics and paleoclimate implications of the extreme precipitation event of March 2015 in northern Chile. Andean Geology, 46(1), 1-31. https://doi.org/10.5027/ andgeoV46n1-3087.

Kereszturi, A., \& Rivera-Valentin, E. G. (2012). Locations of thin liquid water layers on present-day Mars. Icarus, 221(1), 289-295. https:// doi.org/10.1016/j.icarus.2012.08.004.

Kirkham, R., Chorlton, J., \& Carriere, J. (1995). Generalized geology of the world; Generalized geological map of the world and linked databases. Geological Survey of Canada, 2915D.

Klindworth, A., Pruesse, E., Schweer, T., Peplies, J., Quast, C., Horn, M., \& Glockner, F. O. (2013). Evaluation of general 16S ribosomal RNA gene PCR primers for classical and next-generation sequencing-based diversity studies. Nucleic Acids Research, 41(1), e1. https:// doi.org/10.1093/nar/gks808.

Knowles, J. R. (1980). Enzyme-catalyzed phosphoryl transfer reactions. Annual Review of Biochemistry, 49, 877-919. https://doi.org/10.1146/ annurev.bi.49.070180.004305.

Kolodny, Y., Luz, B., \& Navon, O. (1983). Oxygen Isotope Variations in Phosphate of Biogenic Apatites. 1. Fish Bone Apatite - Rechecking the Rules of the Game. Earth and Planetary Science Letters, 64(3), 398-404. https://doi.org/10.1016/0012-821x(83)90100-0.

Komatsu, G., \& Ori, G. G. (2000). Exobiological implications of potential sedimentary deposits on Mars. Planetary and Space Science, 48(11), 1043-1052. https://doi.org/10.1016/S0032-0633(00)00078-7.

Kouno, K., Tuchiya, Y., \& Ando, T. (1995). Measurement of Soil Microbial Biomass Phosphorus by an Anion-Exchange Membrane Method. Soil Biology \& Biochemistry, 27(10), 1353-1357. https://doi. org/10.1016/0038-0717(95)00057-L.

Kreuzeder, A. (2011). Modelling phosphorus flows in soils. Göttingen: Optimus-Verlag.

Lester, E. D., Satomi, M., \& Ponce, A. (2007). Microflora of extreme arid Atacama Desert soils. Soil Biology \& Biochemistry, 39(2), 704-708. https://doi.org/10.1016/j.soilbio.2006.09.020.

Liang, Y., \& Blake, R. E. (2006). Oxygen isotope signature of P-i regeneration from organic compounds by phosphomonoesterases and photooxidation. Geochimica Et Cosmochimica Acta, 70(15), 3957-3969. https://doi.org/10.1016/j.gca.2006.04.036.

Liang, Y., \& Blake, R. E. (2009). Compound- and enzyme-specific phosphodiester hydrolysis mechanisms revealed by delta O-18 of dissolved inorganic phosphate: Implications for marine $\mathrm{P}$ cycling. Geochimica Et Cosmochimica Acta, 73(13), 3782-3794. https://doi. org/10.1016/j.gca.2009.01.038.

Louca, S., \& Doebeli, M. (2018). Efficient comparative phylogenetics on large trees. Bioinformatics, 34(6), 1053-1055. https://doi. org/10.1093/bioinformatics/btx701.

Lucassen, E. C. H. E. T., Smolders, A. J. P., Lamers, L. P. M., \& Roelofs, J. G. M. (2005). Water table fluctuations and groundwater supply are important in preventing phosphate-eutrophication in sulphate-rich fens: Consequences for wetland restoration. Plant and Soil, 269(1-2), 109-115. https://doi.org/10.1007/s11104-004-0554-3.

Makhalanyane, T. P., Valverde, A., Gunnigle, E., Frossard, A., Ramond, J. B., \& Cowan, D. A. (2015). Microbial ecology of hot desert edaphic systems. FEMS Microbiol Rev, 39(2), 203-221. https://doi. org/10.1093/femsre/fuu011.

Malin, M. C., \& Edgett, K. S. (2003). Evidence for persistent flow and aqueous sedimentation on early Mars. Science, 302(5652), 19311934. https://doi.org/10.1126/science.1090544.

Markel, D., Kolodny, Y., Luz, B., \& Nishri, A. (1994). Phosphorus cycling and phosphorus sources in Lake Kinneret: tracing by oxygen isotopes in phosphate. Israel Journal of Earth Sciences, 43(3-4), 165-178.

Martinez, G. M., \& Renno, N. O. (2013). Water and Brines on Mars: Current Evidence and Implications for MSL. Space Science Reviews, 175(1-4), 29-51. https://doi.org/10.1007/s11214-012-9956-3. 
Mclsaac, G. F., David, M. B., Gertner, G. Z., \& Goolsby, D. A. (2001). Eutrophication - Nitrate flux in the Mississippi river. Nature, 414(6860), 166-167. https://doi.org/10.1038/35102672.

McKay, C. P., Friedmann, E. I., Gomez-Silva, B., Caceres-Villanueva, L., Andersen, D. T., \& Landheim, R. (2003). Temperature and moisture conditions for life in the extreme arid region of the Atacama Desert: Four years of observations including the El Nino of 1997-1998. Astrobiology, 3(2), 393-406. https://doi.org/10.1089/1531107037 69016460.

Mclaughlin, M. J., Alston, A. M., \& Martin, J. K. (1986). Measurement of Phosphorus in the Soil Microbial Biomass - a Modified Procedure for Field Soils. Soil Biology \& Biochemistry, 18(4), 437-443. https://doi. org/10.1016/0038-0717(86)90050-7.

Meng, J., Yao, Q. Z., \& Yu, Z. G. (2014). Particulate phosphorus speciation and phosphate adsorption characteristics associated with sediment grain size. Ecological Engineering, 70, 140-145. https://doi. org/10.1016/j.ecoleng.2014.05.007.

Meslin, P. Y., Gasnault, O., Forni, O., Schroder, S., Cousin, A., Berger, G., ... Team, M. S. (2013). Soil Diversity and Hydration as Observed by ChemCam at Gale Crater, Mars. Science, 341(6153), 1238670. https://doi.org/10.1126/science.1238670.

Michalski, G., Bohlke, J. K., \& Thiemens, M. (2004). Long term atmospheric deposition as the source of nitrate and other salts in the Atacama Desert, Chile: New evidence from mass-independent oxygen isotopic compositions. Geochimica Et Cosmochimica Acta, 68(20), 4023-4038. https://doi.org/10.1016/j.gca.2004.04.009.

Mizota, C., Domon, Y., \& Yoshida, N. (1992). Oxygen Isotope Composition of Natural Phosphates from Volcanic Ash Soils of the Great RiftValley of Africa and East Java, Indonesia. Geoderma, 53(1-2), 111123. https://doi.org/10.1016/0016-7061(92)90025-3.

Mooney, H. A., Gulmon, S. L., Ehleringer, J., \& Rundel, P. W. (1980). Atmospheric Water-Uptake by an Atacama Desert Shrub. Science, 209(4457), 693-694. https://doi.org/10.1126/scien ce.209.4457.693.

Murphy, J., \& Riley, J. P. (1962). A Modified Single Solution Method for Determination of Phosphate in Natural Waters. Analytica Chimica Acta, 26(1), 31

Nahas, E. (1996). Factors determining rock phosphate solubilization by microorganisms isolated from soil. World Journal of Microbiology \& Biotechnology, 12(6), 567-572. https://doi.org/10.1007/Bf00327716.

Navarro-Gonzalez, R., Rainey, F. A., Molina, P., Bagaley, D. R., Hollen, B. J., de la Rosa, J., ... McKay, C. P. (2003). Mars-like soils in the Atacama Desert, Chile, and the dry limit of microbial life. Science, 302(5647), 1018-1021. https://doi.org/10.1126/science.1089143.

Oberlin, E. A., Claire, M. W., \& Kounaves, S. P. (2018). Evaluation of the Tindouf Basin Region in Southern Morocco as an Analog Site for Soil Geochemistry on Noachian Mars. Astrobiology, 18(10), 1318-1328. https://doi.org/10.1089/ast.2016.1557.

Oburger, E., Jones, D. L., \& Wenzel, W. W. (2011). Phosphorus saturation and $\mathrm{pH}$ differentially regulate the efficiency of organic acid anion-mediated $\mathrm{P}$ solubilization mechanisms in soil. Plant and Soil, 341(1-2), 363-382. https://doi.org/10.1007/s11104-010-0650-5.

Olivares, D., Ferrada, P., de Matos, C., Marzo, A., Cabrera, E., Portillo, C., \& Llanos, J. (2017). Characterization of soiling on PV modules in the Atacama Desert. Energy Procedia, 124, 547-553. https://doi. org/10.1016/j.egypro.2017.09.263.

Olsen, S. R. (1954). Estimation of available phosphorus in soils by ex traction with sodium bicarbonate. U.S. Department of Agriculture Circular, 939, 1-19.

Orlando, J., Alfaro, M., Bravo, L., Guevara, R., \& Caru, M. (2010). Bacterial diversity and occurrence of ammonia-oxidizing bacteria in the Atacama Desert soil during a "desert bloom" event. Soil Biology \& Biochemistry, 42(7), 1183-1188. https://doi.org/10.1016/j.soilb io.2010.03.025.
Osorio, N. W., \& Habte, M. (2013). Phosphate desorption from the surface of soil mineral particles by a phosphate-solubilizing fungus. Biology and Fertility of Soils, 49(4), 481-486. https://doi.org/10.1007/ s00374-012-0763-5.

Palacio, S., Azorin, J., Montserrat-Marti, G., \& Ferrio, J. P. (2014). The crystallization water of gypsum rocks is a relevant water source for plants. Nature Communications, 5, 4660. https://doi.org/10.1038/ ncomms5660.

Passariello, C., Forleo, C., Micheli, V., Schippa, S., Leone, R., Mangani, S., ... Rossolini, G. M. (2006). Biochemical characterization of the class B acid phosphatase (AphA) of Escherichia coli MG1655. Biochimica Et Biophysica Acta-Proteins and Proteomics, 1764(1), 13-19. https://doi. org/10.1016/j.bbapap.2005.08.028.

Pistocchi, C., Tamburini, F., Gruau, G., Ferhi, A., Trevisan, D., \& Dorioz, J. M. (2017). Tracing the sources and cycling of phosphorus in river sediments using oxygen isotopes: Methodological adaptations and first results from a case study in France. Water Research, 111, 346-356. https://doi.org/10.1016/j.watres.2016.12.038.

Quast, C., Pruesse, E., Yilmaz, P., Gerken, J., Schweer, T., Yarza, P. ... Glockner, F. O. (2013). The SILVA ribosomal RNA gene database project: improved data processing and web-based tools. Nucleic Acids Research, 41(D1), D590-D596. https://doi.org/10.1093/ nar/gks1219.

Rech, J. A., Currie, B. S., Shullenberger, E. D., Dunagan, S. P., Jordan, T. E., Blanco, N., ... Houston, J. (2010). Evidence for the development of the Andean rain shadow from a Neogene isotopic record in the Atacama Desert. Chile. Earth and Planetary Science Letters, 292(3-4), 371-382. https://doi.org/10.1016/j. epsl.2010.02.004.

Rech, J. A., Quade, J., \& Hart, W. S. (2003). Isotopic evidence for the source of $\mathrm{Ca}$ and $\mathrm{S}$ in soil gypsum, anhydrite and calcite in the Atacama Desert. Chile. Geochimica Et Cosmochimica Acta, 67(4), 575586. https://doi.org/10.1016/S0016-7037(02)01175-4.

Reddy, K. R., Wetzel, R. G., \& Kadlec, R. H. (2005). Biogeochemistry of phosphorus in wetlands. Phosphorus: Agriculture and the environment(phosphorusagric), 263-316.

Reed, S. C., \& Wood, T. E. (2016). Soil phosphorus cycling in tropical soils: an ultisol and oxisol perspective.

Rognes, T., Flouri, T., Nichols, B., Quince, C., \& Mahe, F. (2016). VSEARCH a versatile open source tool for metagenomics. PeerJ, 4, e2584. https://doi.org/10.7717/peerj.2584.

Scervino, J. M., Mesa, M. P., Della Monica, I., Recchi, M., Moreno, N. S., \& Godeas, A. (2010). Soil fungal isolates produce different organic acid patterns involved in phosphate salts solubilization. Biology and Fertility of Soils, 46(7), 755-763. https://doi.org/10.1007/s0037 4-010-0482-8.

Scheihing, K. W., Moya, C. E., Struck, U., Lictevout, E., \& Troger, U. (2018). Reassessing Hydrological Processes That Control Stable Isotope Tracers in Groundwater of the Atacama Desert (Northern Chile). Hydrology, 5(1), 3. https://doi.org/10.3390/hydrology5010003.

Schenk, C. J., Viger, R. J., \& Anderson, C. P. (1999). Maps showing geology, oil and gas fields, and geological provinces of South America.

Schindler, D., \& Vallentyne, J. (2008). The algal bowl: overfertilization of the world's freshwaters and estuaries Edmonton. In: Alberta, Canada: University of Alberta Press.

Schotterer, U., Oldfield, F., \& Fröhlich, K. (1996). GNIP. Global Network for Isotopes in Precipitation.

Schulze-Makuch, D., Wagner, D., Kounaves, S. P., Mangelsdorf, K., Devine, K. G., de Vera, J. P., ... Zamorano, P. (2018). Transitory microbial habitat in the hyperarid Atacama Desert. Proceedings of the National Academy of Sciences of the United States of America, 115(11), 2670-2675. https://doi.org/10.1073/pnas.1714341115.

Sharma, S. B., Sayyed, R. Z., Trivedi, M. H., \& Gobi, T. A. (2013). Phosphate solubilizing microbes: sustainable approach for managing phosphorus 
deficiency in agricultural soils. Springerplus, 2, 587. https://doi. org/10.1186/2193-1801-2-587.

Sheldon, R. P. (1982). Phosphate Rock. Scientific American, 246(6), 45. https://doi.org/10.1038/scientificamerican0682-45.

Shemesh, A., Kolodny, Y., \& Luz, B. (1983). Oxygen Isotope Variations in Phosphate of Biogenic Apatites. 2. Phosphorite Rocks. Earth and Planetary Science Letters, 64(3), 405-416. https://doi. org/10.1016/0012-821x(83)90101-2.

Shemesh, A., Kolodny, Y., \& Luz, B. (1988). Isotope Geochemistry of Oxygen and Carbon in Phosphate and Carbonate of Phosphorite Francolite. Geochimica Et Cosmochimica Acta, 52(11), 2565-2572. https://doi.org/10.1016/0016-7037(88)90027-0.

Shen, J., Zerkle, A. L., Stueken, E. E., \& Claire, M. W. (2019). Nitrates as a Potential $N$ Supply for Microbial Ecosystems in a Hyperarid Mars Analog System. Life, 9(4), 79. https://doi. org/10.3390/life9040079.

Smith, P. H., Tamppari, L. K., Arvidson, R. E., Bass, D., Blaney, D., Boynton, W. V., ... Zent, A. P. (2009). $\mathrm{H} 2 \mathrm{O}$ at the Phoenix Landing Site. Science, 325(5936), 58-61. https://doi.org/10.1126/science.1172339.

Smolders, A. J. P., Lucassen, E. C. H. E. T., Bobbink, R., Roelofs, J. G. M., \& Lamers, L. P. M. (2010). How nitrate leaching from agricultural lands provokes phosphate eutrophication in groundwater fed wetlands: the sulphur bridge. Biogeochemistry, 98(1-3), 1-7. https://doi. org/10.1007/s10533-009-9387-8.

Stevenson, A., Burkhardt, J., Cockell, C. S., Cray, J. A., Dijksterhuis, J., Fox-Powell, M., ... Hallsworth, J. E. (2015). Multiplication of microbes below 0.690 water activity: implications for terrestrial and extraterrestrial life. Environmental Microbiology, 17(2), 257-277. https://doi. org/10.1111/1462-2920.12598.

Stomeo, F., Valverde, A., Pointing, S. B., Mckay, C. P., Warren-Rhodes, K. A., Tuffin, M. I., ... Cowan, D. A. (2013). Hypolithic and soil microbial community assembly along an aridity gradient in the Namib Desert. Extremophiles, 17(2), 329-337. https://doi.org/10.1007/ s00792-013-0519-7.

Stout, L. M., Joshi, S. R., Kana, T. M., \& Jaisi, D. P. (2014). Microbial activities and phosphorus cycling: An application of oxygen isotope ratios in phosphate. Geochimica Et Cosmochimica Acta, 138, 101-116. https://doi.org/10.1016/j.gca.2014.04.020.

Strauch, G., Oyarzun, J., Fiebig-Wittmaack, M., Gonzalez, E., \& Weise, S. M. (2006). Contributions of the different water sources to the Elqui river runoff (northern Chile) evaluated by $\mathrm{H} / \mathrm{O}$ isotopes. Isotopes in Environmental and Health Studies, 42(3), 303-322. https://doi. org/10.1080/10256010600839707.

Sun, T., Bao, H. M., Reich, M., \& Hemming, S. R. (2018). More than ten million years of hyper-aridity recorded in the Atacama Gravels. Geochimica Et Cosmochimica Acta, 227, 123-132. https://doi. org/10.1016/j.gca.2018.02.021.

Surma, J., Assonov, S., Herwartz, D., Voigt, C., \& Staubwasser, M. (2018). The evolution of $\mathrm{O}-17$-excess in surface water of the arid environment during recharge and evaporation. Scientific Reports, 8, 4972. https://doi.org/10.1038/s41598-018-23151-6.

Takahashi, K., \& Battisti, D. S. (2007). Processes controlling the mean tropical pacific precipitation pattern. Part II: The SPCZ and the southeast pacific dry zone. Journal of Climate, 20(23), 5696-5706. https://doi.org/10.1175/2007jcli1656.1.

Tamburini, F., Bernasconi, S. M., Angert, A., Weiner, T., \& Frossard, E. (2010). A method for the analysis of the delta O-18 of inorganic phosphate extracted from soils with $\mathrm{HCl}$. European Journal of Soil Science, 61(6), 1025-1032. https://doi. org/10.1111/j.1365-2389.2010.01290.x.

Tamburini, F., Pfahler, V., Bunemann, E. K., Guelland, K., Bernasconi, S. M., \& Frossard, E. (2012). Oxygen Isotopes Unravel the Role of Microorganisms in Phosphate Cycling in Soils. Environmental Science \& Technology, 46(11), 5956-5962. https://doi.org/10.1021/es300 311h.
Tamburini, F., Pfahler, V., von Sperber, C., Frossard, E., \& Bernasconi, S. M. (2014). Oxygen Isotopes for Unraveling Phosphorus Transformations in the Soil-Plant System: A Review. Soil Science Society of America Journal, 78(1), 38-46. https://doi.org/10.2136/ sssaj2013.05.0186dgs.

Tamburini, F., Pistocchi, C., Helfenstein, J., \& Frossard, E. (2018). A method to analyse the isotopic composition of oxygen associated with organic phosphorus in soil and plant material. European Journal of Soil Science, 69(5), 816-826. https://doi. org/10.1111/ejss.12693.

Tapia, J., Gonzalez, R., Townley, B., Oliveros, V., Alvarez, F., Aguilar, G., ... Calderon, M. (2018). Geology and geochemistry of the Atacama Desert. Antonie Van Leeuwenhoek International Journal of General and Molecular Microbiology, 111(8), 1273-1291. https://doi.org/10.1007/ s10482-018-1024-x.

Tian, H. Q., Chen, G. S., Zhang, C., Melillo, J. M., \& Hall, C. A. S. (2010). Pattern and variation of C:N: P ratios in China's soils: a synthesis of observational data. Biogeochemistry, 98(1-3), 139-151. https://doi. org/10.1007/s10533-009-9382-0.

Trewartha, G. T. (1961). The earth's problem climates (551.59 T817). Retrieved from.

Tudge, A. P. (1960). A Method of Analysis of Oxygen Isotopes in Orthophosphate - Its Use in the Measurement of Paleotemperatures. Geochimica Et Cosmochimica Acta, 18(1-2), 81-93. https://doi. org/10.1016/0016-7037(60)90019-3.

Uritskiy, G., Getsin, S., Munn, A., Gomez-Silva, B., Davila, A., Glass, B., ... DiRuggiero, J. (2019). Halophilic microbial community compositional shift after a rare rainfall in the Atacama Desert. The ISME Journal, 13(11), 2737-2749. https://doi.org/10.1038/s41396-019-0468-y.

Urrutia, O., Erro, J., Guardado, I., San Francisco, S., Mandado, M., Baigorri, R., ... Garcia-Mina, J. M. (2014). Physico- chemical characterization of humic- metal- phosphate complexes and their potential application to the manufacture of new types of phosphate- based fertilizers. Journal of Plant Nutrition and Soil Science, 177(2), 128-136. https:// doi.org/10.1002/jpln.201200651.

Vangeel, B., Mur, L. R., Ralskajasiewiczowa, M., \& Goslar, T. (1994). Fossil Akinetes of Aphanizomenon and Anabaena as Indicators for Medieval Phosphate-Eutrophication of Lake Gosciaz (Central Poland). Review of Palaeobotany and Palynology, 83(1-3), 97-105. https://doi.org/10.1016/0034-6667(94)90061-2.

Veblen, T. T., Young, K. R., \& Orme, A. R. (2015). The physical geography of South America. Oxford: Oxford University Press.

Vidiella, P. E., Armesto, J. J., \& Gutierrez, J. R. (1999). Vegetation changes and sequential flowering after rain in the southern Atacama Desert. Journal of Arid Environments, 43(4), 449-458. https://doi. org/10.1006/jare.1999.0565.

Vitousek, P. M., Porder, S., Houlton, B. Z., \& Chadwick, O. A. (2010). Terrestrial phosphorus limitation: mechanisms, implications, and nitrogen-phosphorus interactions. Ecological Applications, 20(1), 5-15. https://doi.org/10.1890/08-0127.1.

von Sperber, C., Kries, H., Tamburini, F., Bernasconi, S. M., \& Frossard, E. J. G. (2014). The effect of phosphomonoesterases on the oxygen isotope composition of phosphate. Geochimica et Cosmochimica Acta, 125, 519-527. https://doi.org/10.1016/j.gca.2013.10.010.

Walker, T. W., \& Syers, J. K. (1976). The fate of phosphorus during pedogenesis. Geoderma, 15(1), 1-19. https://doi.org/10.1016/00167061(76)90066-5.

Weckwerth, G., \& Schidlowski, M. (1995). Phosphorus as a potential guide in the search for extinct life on Mars. Advances in Space Research, 15(3), 185-191.

Xiao, J., Porter, S. C., An, Z. S., Kumai, H., \& Yoshikawa, S. (1995). Grain-Size of Quartz as an Indicator of Winter Monsoon Strength on the Loess Plateau of Central China during the Last 130,000Yr. Quaternary Research, 43(1), 22-29. https://doi.org/10.1006/ qres.1995.1003. 
Ye, Y. Z., \& Doak, T. G. (2009). A Parsimony Approach to Biological Pathway Reconstruction/Inference for Genomes and Metagenomes. Plos Computational Biology, 5(8), e1000465. https://doi.org/10.1371/ journal.pcbi.1000465.

Yen, A. S., Mittlefehldt, D. W., McLennan, S. M., Gellert, R., Bell, J. F., McSween, H. Y., ... Squyres, S. W. (2006). Nickel on Mars: Constraints on meteoritic material at the surface. Journal of Geophysical ResearchPlanets, 111(E12), 2797. https://doi.org/10.1029/2006je002797.
How to cite this article: Shen J, Smith AC, Claire MW, Zerkle AL. Unraveling biogeochemical phosphorus dynamics in hyperarid Mars-analogue soils using stable oxygen isotopes in phosphate. Geobiology. 2020;00:1-20. https://doi. org/10.1111/gbi.12408 